\title{
How Much of Canada's Unemployment Is Structural?
}

\author{
by Lars Osberg* and Zhengxi Lin**
}

No. 145

\author{
11F0019MPE No. 145 \\ ISSN: 1200-5223 \\ ISBN: 0-660-18060-X
}

Price: $\$ 5.00$ per issue, $\$ 25.00$ annually

Business and Labour Market Analysis Division

24, R.H. Coats Building, Ottawa, K1A 0T6

*Dalhousie University (902) 494-6988

**Statistics Canada (613) 951-0830

osberg@is.dal.ca

linzhen@statcan.ca

Facsimile Number: (613) 951-5403

The paper is available on Internet: (www.statcan.ca)

\section{October 2000}

Views expressed in the paper are those of the authors and do not necessarily reflect those of the authors' respective affiliations. Lars Osberg would like to thank Lynn Lethbridge for her excellent work as research assistant and the Social Sciences and Humanities Research Council for financial support under Grant 410-97-0802; Zhengxi Lin would like to thank Lin Bian for his help with data construction. Earlier versions were presented at "The Structural Aspects of Unemployment in Canada" conference organized by the Centre for the Study of Living Standards (CSLS), Ottawa, April 22-23, 1999 and the 1999 Canadian Economics Association (CEA) meetings. The authors gratefully acknowledge helpful comments and suggestions from Pierre Fortin, Noah Meltz, Alice Nakamura, Frank Reid, Craig Riddell, Andrew Sharpe, Jean-Pierre Voyer, and the CSLS and CEA conferences participants. The authors are solely responsible for any errors remaining in the paper. This paper represents the views of the authors and does not necessarily reflect the opinions of Statistics Canada. 


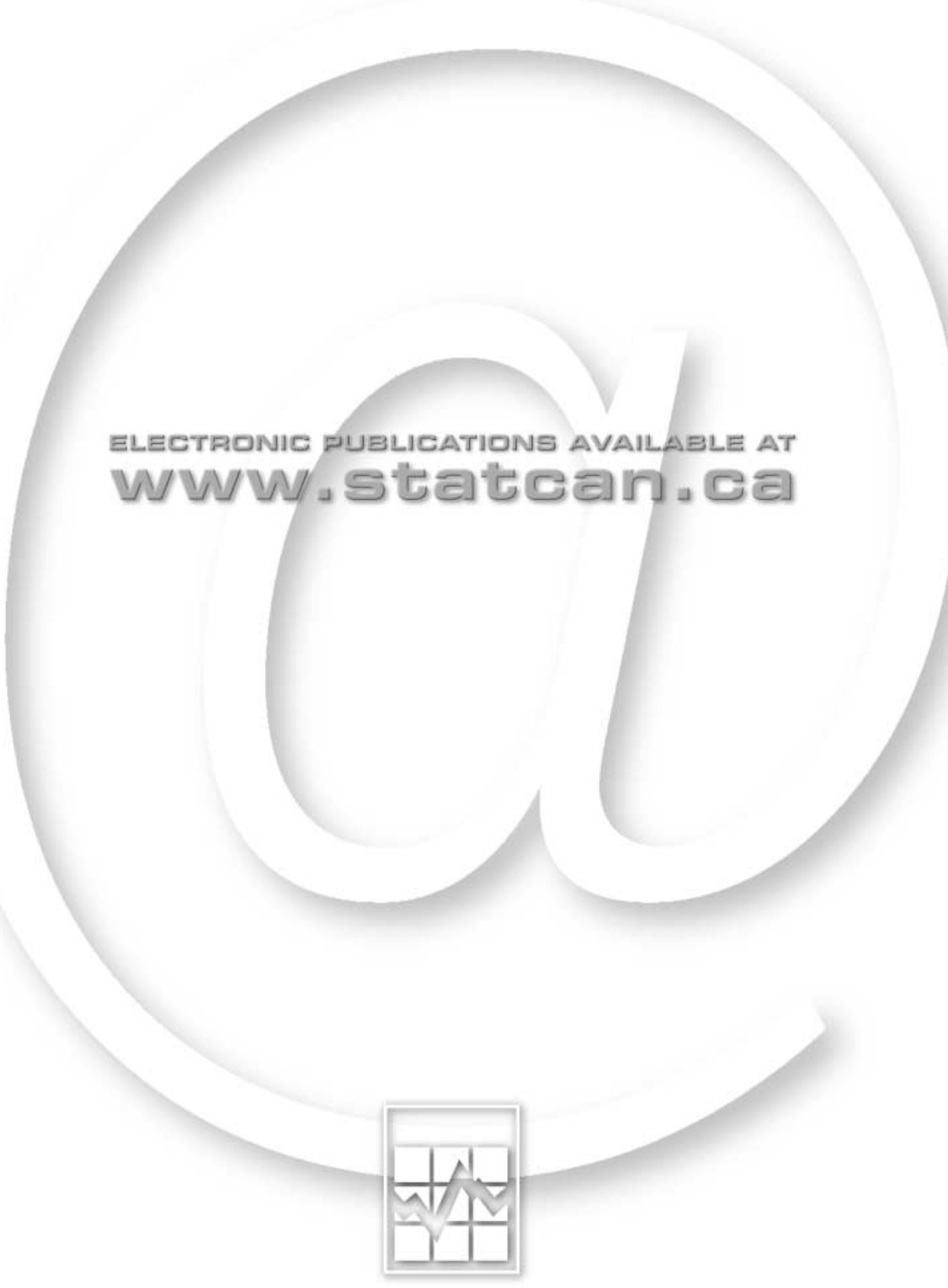




\section{Table of Contents}

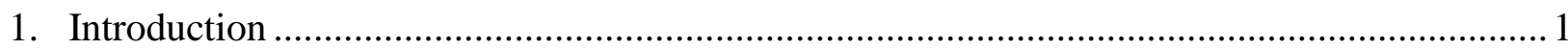

2.1 Miscellaneous Surveys and Headlines ....................................................................... 3

2.2 The Workplace and Employee Survey (WES 1996) ...............................................5

2.3 The Help-Wanted Index/Unemployment Rate Relationship .................................... 6

2.4 The Help-Wanted Index and the Number of Vacancies ......................................... 10

2.5 The Vacancy Rate/Help-Wanted Index Relationship ........................................... 11

2.5.1 The "Old" and the "New" Help-Wanted Index ................................................ 11

2.5.2 Modelling the Vacancy Rates ....................................................................... 13

2.5.3 Predicting Job Vacancies for the 1980s and 1990s........................................ 16

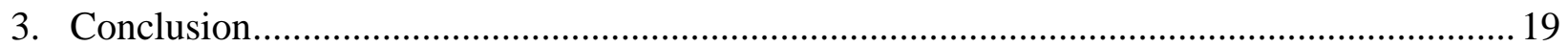

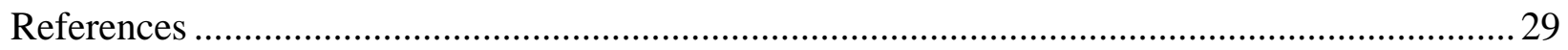




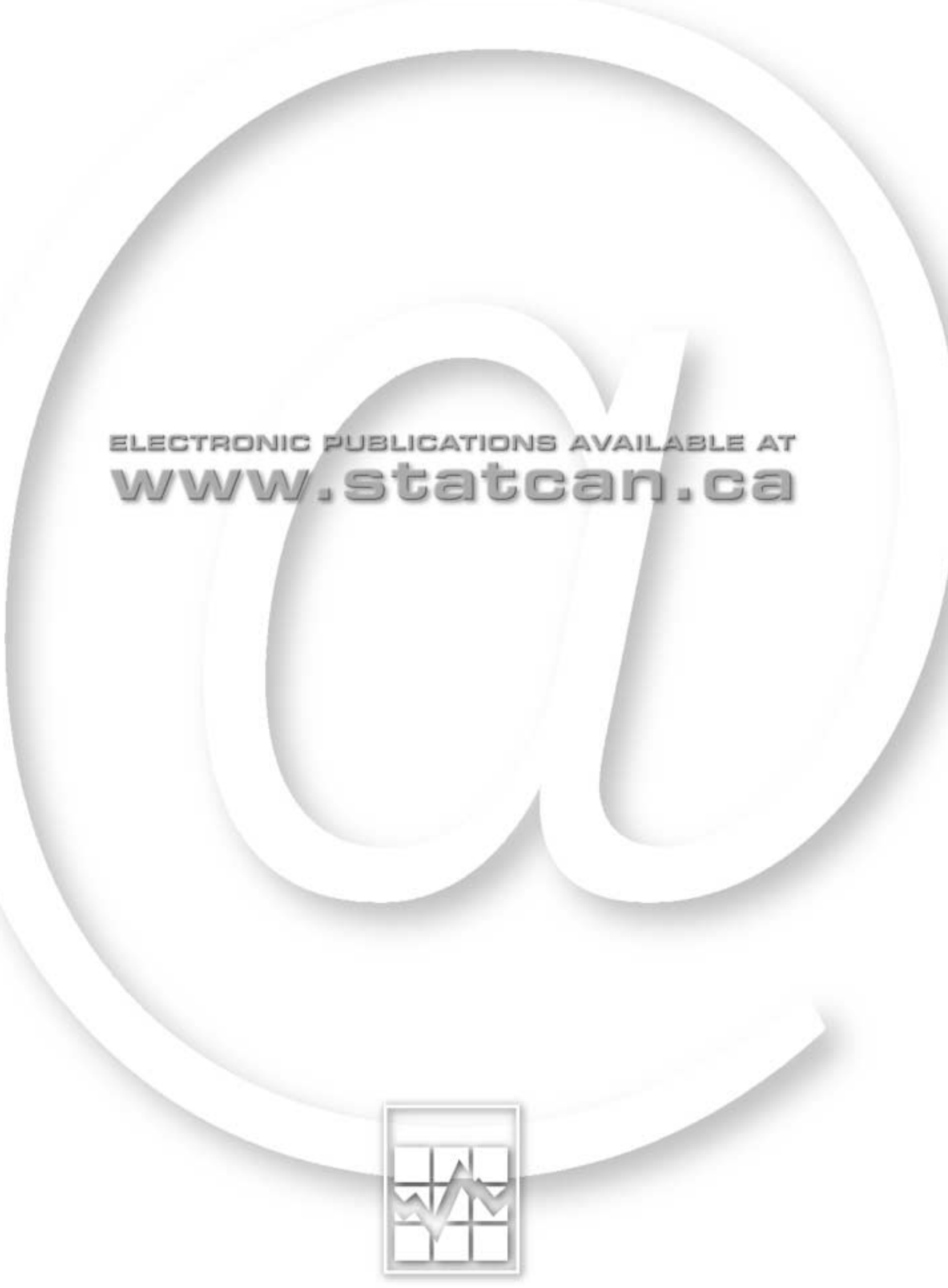




\section{ABSTRACT}

This paper starts from the definition that "structural unemployment occurs when workers are unable to fill available jobs because they lack the skills, do not live where jobs are available, or are unwilling to work at the wage rate offered in the market." This implies that the number of vacancies in the Canadian labour market is an upper bound to the extent of "structural unemployment". The paper summarizes available estimates of the vacancy rate in Canada. In the high technology sector, vacancies may be equivalent to $2.2 \%$ of the labour force but evidence from more representative surveys indicates a range of $0.43 \%$ to $0.75 \%$ for the economy as a whole. Although during the 1980s the outward shift in the relationship between the Help-Wanted Index and the unemployment rate raised concerns that structural unemployment was an increasing problem in Canada, that shift has been reversed in the 1990s.

Keywords: Structural unemployment, unemployment rates, vacancy rates, Help-Wanted Index, Job Vacancy Survey

JEL Classification: E24, J63, J64 


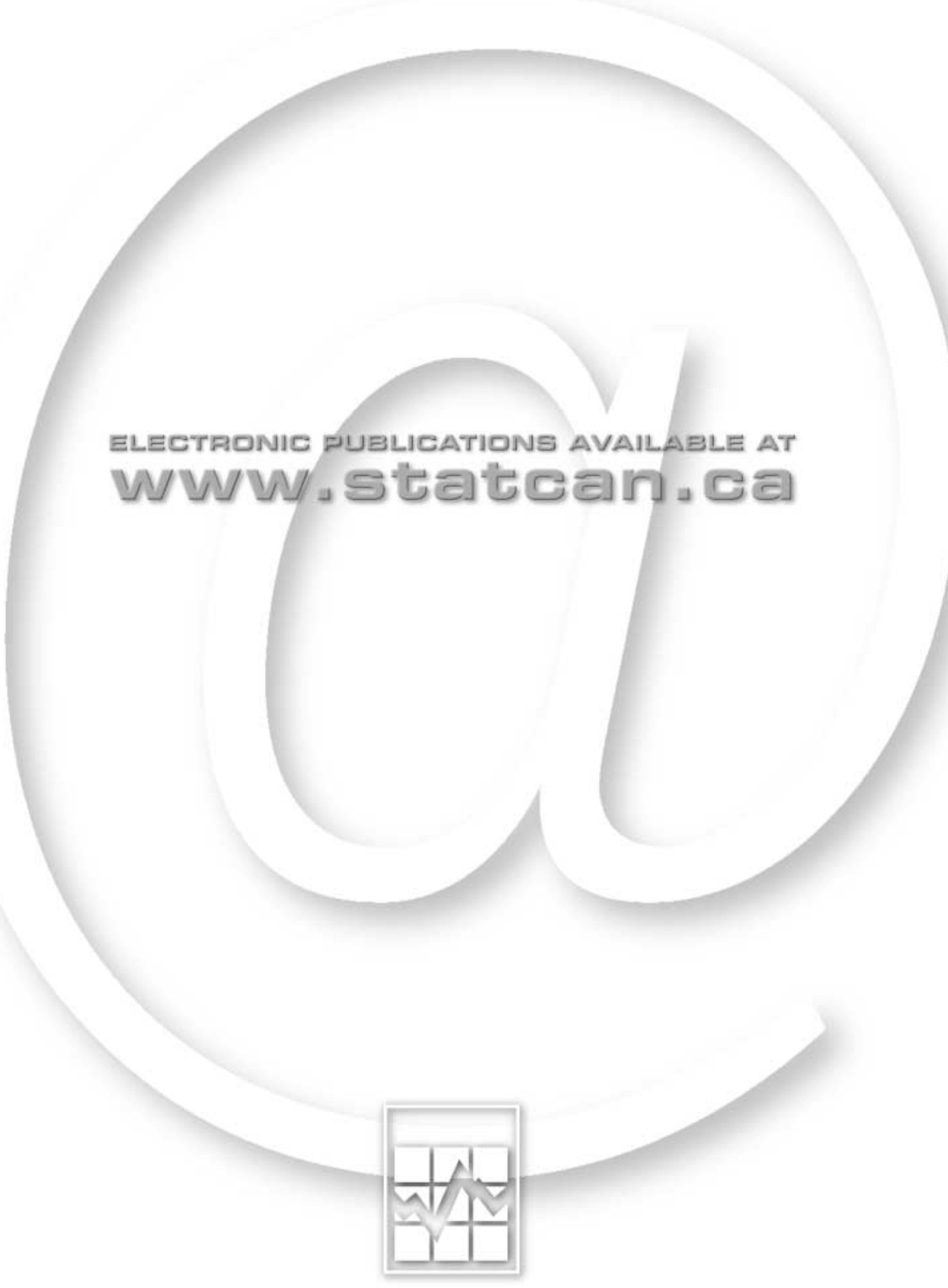




\section{Introduction}

The objective of this paper is to estimate the fraction of Canada's current unemployment that is "structural" in nature, but why does the issue matter? One reason is microeconomic in orientation. If much of Canada's current unemployment is due to a mismatch between the characteristics of Canada's unemployed and of available job vacancies, then more effort in retraining, mobility and other labour market adjustment policies to increase the "flexibility" of the Canadian labour market may be appropriate. A second reason, from a macroeconomic perspective, is that when price stability ${ }^{1}$ has become the only objective of monetary policy, monetary authorities will see it as crucial to avoid any chance that aggregate demand might exceed aggregate potential output. Assessing the relative importance of structural unemployment, compared to the fraction of current unemployment that is due to aggregate demand deficiency, is therefore crucial to macroeconomic policy setting. ${ }^{2}$

What exactly is structural unemployment? Debates on economic policy can easily degenerate into confusion if the same term is used with different meanings, and structural unemployment has found a variety of definitions in macroeconomics and labour economics over the years (see Appendix A). This paper adopts the definition advocated by Finance Canada: "Structural unemployment occurs when workers are unable to fill available jobs because they lack the skills, do not live where jobs are available, or are unwilling to work at the wage rate offered in the market".

Although some definitions of "structural unemployment" have interpreted it more loosely to mean "long term and chronic unemployment", such a definition leaves its origins unexplained. Furthermore, if structural unemployment is defined to be "long term and chronic" unemployment, it is clearly circular to argue that structural unemployment is the cause of long term and chronic unemployment. The Finance Canada definition therefor has two major advantages: (1) a close fit with the normal usage of the term "structural unemployment" in the labour economics literature $;{ }^{5}$ (2) the possibility of empirical examination, independent of the aggregate unemployment which structural unemployment seeks to explain. If structural unemployment occurs when workers are unable to fill available jobs, the number of available

1 Operationally defined as the core rate of consumer price inflation in the range of $1 \%$ to $3 \%$ per annum (in practice, deviations below $1 \%$ inflation have been tolerated).

2 More exactly, the extent of structural unemployment matters for those estimates of potential output that have an underlying economic content --- see Dupasquier et al (1997) for alternative examples of purely statistical methodology. On the other hand, although disagreeing on some other issues, both Jackson (1998) and Sargent and Sheikh (1996) would agree on the potential importance of structural mismatch for macroeconomic policy.

3 Finance Canada web page http://www.fin.gc.ca/glosse/gloss8e.html.

4 See, for example, Abel, Bernanke and Smith (1999:94).

5 In labour economics, "unwilling to work at the wage rate offered in the market" is not normally part of the definition --- see appendix A. 
jobs sets an upper bound to the level of structural unemployment. ${ }^{6}$ Empirical measurement of job vacancies is therefore crucial. Hence, the empirical strategy of this paper is to present estimates of the number of vacancies in the Canadian labour market using data from the Workplace and Employee Survey (WES), the Help-Wanted Index (HWI) and historical vacancy data from the Job Vacancy Survey (JVS).

Session 2.1 begins by considering what can be learned from some of the ad hoc surveys which generate headlines on skill shortages in the press. Section 2.2 then discusses the snapshot of vacancies obtained with direct questioning of employers in the WES. Section 2.3 examines the relationship between the Help-Wanted Index and the unemployment rate in the 1980s and 1990s. Section 2.4 looks at how the HWI has been used by other authors to estimate a trend in aggregate vacancies over time. Section 2.5 then asks what can be learned from the relationship between direct observation of vacancies in the Job Vacancy Survey and movements in the Help-Wanted Index since that survey was discontinued. Section 3 is a conclusion.

Although some authors (e.g., Burdett and Cunningham (1994:148) use the term "vacancy" to include future openings, ${ }^{7}$ in this paper we need a concept that is comparable with the current stock of unemployed workers - hence we restrict the term "vacancy" to mean an unoccupied position that is potentially immediately available to an external candidate. Because most jobs are filled by an interview process with a future start date, most labour market matching activity proceeds without ever generating either unemployment or a vacancy thus defined ${ }^{8}$ [e.g., a graduate student who goes directly from being a teaching assistant to being a professor]. However, if the hypothesis of structural unemployment is to be used to explain some fraction of the stock of people currently unemployed (i.e., immediately available for jobs), a comparable measure of the current stock of available jobs is required.

6 The number of immediately available vacancies is an upper bound to the extent of structural unemployment because even if all the unemployed were in the location where jobs were available, had the skills demanded and were willing to accept the wage offered, it might still take time for workers and firms to match up with each other. The time which firms require to search for suitable workers implies that some vacancies are "frictional" in the same way (and for the same reasons) that some unemployment is "frictional". In addition, the Finance Canada definition classifies as structurally unemployed those workers "unwilling to work at the wage rate offered in the market" (Emphasis added). Firms which have positions available at substantially less pay than the going market wage (or with substantially poorer working conditions) may advertise "vacancies". However, although one might reasonably call such vacancies with below market pay rates "structural vacancies", the unemployed who refuse such substandard jobs (but who would accept at the market wage) are not "structurally" unemployed.

Although the WES data distinguishes between long duration and short duration vacancies and might be seen as approximating a frictional/structural distinction in vacancies (see Section 2.3), this paper does not attempt to subtract the number of frictional and substandard vacancies from "available jobs".

7 Following at least in spirit the standard definition of an unemployed worker, a firm will be said to have a vacancy if it is willing to allocate resources to obtain a positive arrival rate of candidates for jobs --- Burdett and Cunningham (1994:148).

8 Using the 1986 Labour Market Activity Survey, Osberg (1991:1710) estimated that 65\% of inter-industry mobility changes in Canada occurred without any intervening period of unemployment. 


\subsection{Miscellaneous Surveys and Headlines}

Although economics is supposed to be a quantitative, rigorous discipline, economists are, in practice, exposed to (and influenced by) a great deal of qualitative, non-rigorous information. Impressions of whether there are many or only a few available jobs are inevitably affected by newspaper headlines about skills shortages in high tech industries — despite the relatively small quantitative importance of this sector. ${ }^{9}$ Perceptions of the extent of structural unemployment are also inevitably influenced by individual case studies - e.g., the powerful imagery of Newfoundland outports devastated by the closure of the cod fishery - despite the very small size of such villages, both absolutely and as percentage of the Canadian population. Since powerful images and compelling anecdotes may have much more emotional impact than statistical tables, the debate on structural unemployment can sometimes become essentially non-quantitative in nature.

However, newspaper headlines do sometimes appeal to statistics. Following these up can be a frustrating experience. In addition to an endemic vagueness about the relevant sampling frame under consideration, journalistic discussion of shortages often shifts casually between vaguely specified measures - sometimes referring to the future hiring intentions of firms (over varying time horizons), "difficulties" encountered by firms in hiring, "concern" over labour availability, reasons for production delays, etc. The normal finding is a pervasive dissatisfaction. As Roy et al (1996) note, in a market system general and persistent shortages will be resolved by the market if employers are willing to pay more, or train more. All the same, "from an (individual) employer's standpoint, skills of employees are always in shortage and it is very easy to elicit positive responses to questions about skill shortages" (1996:25).

Tracking down the source of assertions of labour shortages can sometimes be a bit like tracking the origins of an urban legend. In essence, there is a lot of anecdotal information but very little "hard" evidence on vacancies and skill shortages. However, Statistics Canada has asked

9 Evans (1999:B8) reports on a survey of 34 high tech companies that currently have 80,000 employees, or $20 \%$ of the high tech workforce in Canada. No further definition of "high tech" is provided, (and the concept is inherently ambiguous) but the article goes on to estimate high tech employment as 400,000 , which is approximately $2.7 \%$ of current employment in Canada.

10 The survey in question was conducted by International Data Corporation and results are available for $\$ 3,500.00$ (Canadian). The wording of questions asked and the construction of the sample frame used are not publicly available, but a telephone inquiry elicited the information that there was a $20 \%$ response rate to a mail back survey of "large" companies. Apparently, the concept in use is "project delay" but what exactly this means, and what reliance can be placed on the survey, is not possible to assess.

11 See http://www.angusreid.com/pressrel/Cata_jun41997.htm

12 Personal communication, Mary Rother, Vice President, Branham Group, April 6, 1999

13 See Branham Group (1999) "IT Skills Shortage in Canada", page 3 --- available from the ITAC web page http://www.itac.ca.

14 See Greater Halifax Partnership (1997:65). The survey was a mail back using the Business Occupancy Tax List for the municipality as the sampling frame. The majority of respondents had less than 5 employees and only 40 
manufacturers a question on "sources of production difficulties" since 1981, ${ }^{16}$ and Figure 1 presents the percentage of manufacturing establishments reporting that "skilled labour shortage" or "unskilled labour shortage" was an impediment to production. This time series has a plausible correlation with the macro economic cycle, and other indicators of labour demand. However, the absolute fraction of manufacturing establishments reporting that labour shortages impeded production is very low (in January 1999, only 5\% of manufacturers reported that skilled labour shortages impeded production, and the percentage reporting unskilled labour shortages was zero).

Presumably, available vacancies are concentrated in the 5\% of manufacturing firms that need skilled workers for production, but since neither the size of the employer nor the number of workers needed is reported, one cannot translate this time series into a vacancy rate. Furthermore, since there is no time dimension to the question in this quarterly survey, there is no way of knowing whether an unfilled job or shortage of overtime hours caused problems for a few hours, or days, or for longer.

(9.1\%) had 50 or more employees. The under representation of employers of significant size makes it highly unclear how one can generalize from recruitment "difficulties" to employment vacancies.

15 The Small Business and Special Survey Division of Statistics Canada has conducted a series of special labour market surveys at the firm level concentrating on wage and salary information for a number of provinces in the 1990s (for example, the 1998 Wage and Salary Survey for Saskatchewan and Prince Edward Island, the 19961997 Wage and Salary Survey for Saskatchewan and Manitoba). Possible measures of vacancy issues are addressed in two questions: "How many workers presently in this occupation do you expect will vacate their positions over the next 12 months?" and "How many additional workers do you expect to hire in this occupation over the next 12 months?" The first is really an expected turnover question, and the second is really an expected hiring question. Both are somewhat related to vacancies, but not the same concept at all.

16 Available on CANSIM: Matrices 2843-2845; The exact question asked is: "Are the production activities of this establishment impeded by difficulties in any of the following areas?" --- shortage of skilled labour and shortage of unskilled labour are the first two options specified, followed by shortage of raw materials (mentioned by $13 \%$ in January 1999), working capital, other and none. 
FIGURE 1

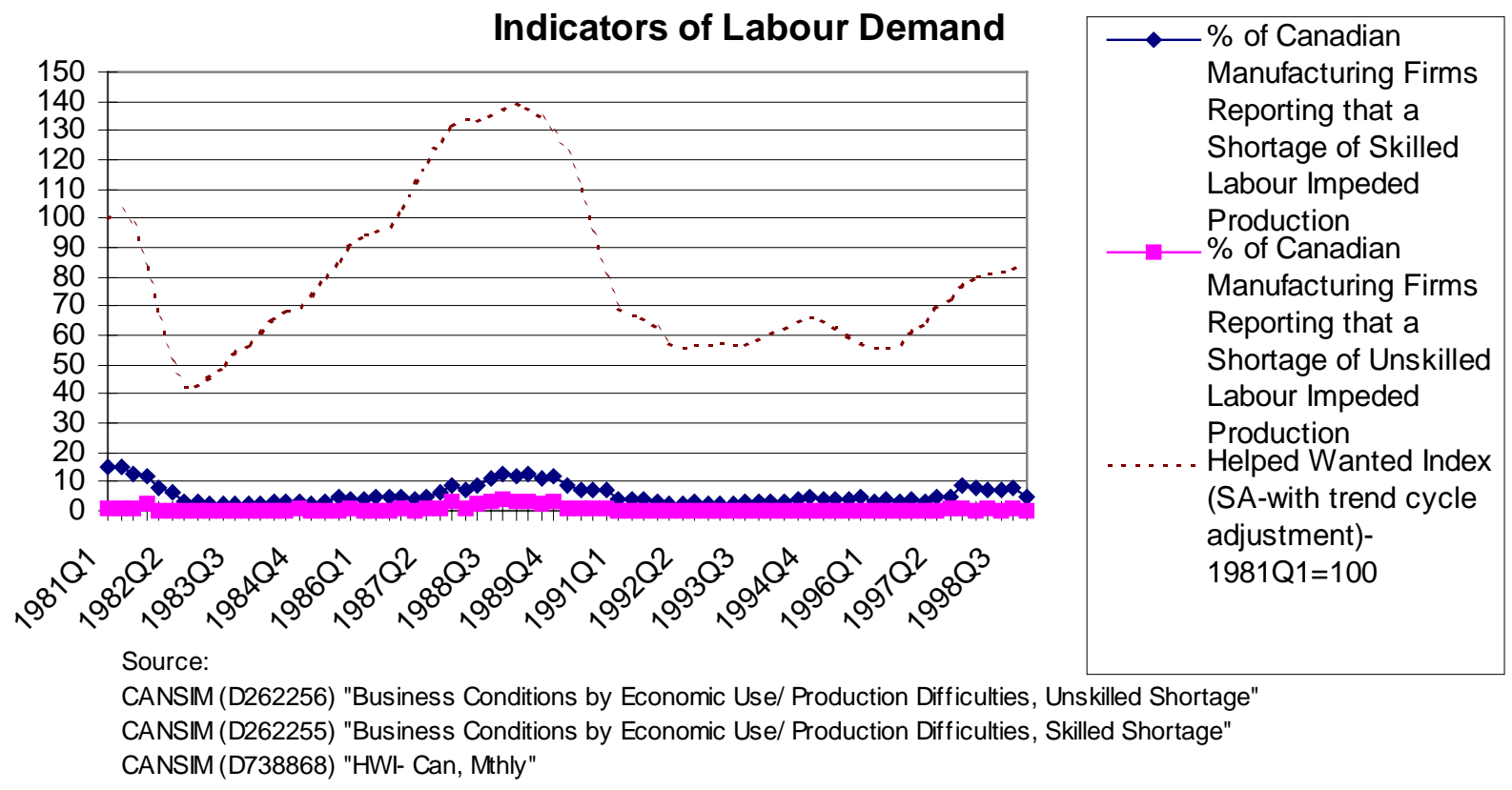

\subsection{The Workplace and Employee Survey (WES 1996)}

In 1996, Statistics Canada collected data from 748 employers using a stratified random sample design based on Statistics Canada's Business Register. As a relatively current indicator of the level of vacancies, this survey is the best available because respondents were drawn from a variety of industrial sectors across Canada (not just the high tech sector or a single locality). As well, the question used directly asks for the total number of current vacancies and the number unfilled for four months or longer. ${ }^{17}$ An especially useful feature of this survey is that it can distinguish between the percentage of firms which are looking for workers or which have vacancies, and vacancies as a percentage of the work force. In the WES, a fifth of all establishments reported active recruitment activities at the time of the survey, but this is a long way from meaning that vacancies were commonplace. Although some $10 \%$ of establishments reported some unfilled positions, these were equivalent to about $1 \%$ of the workforce at the time of the survey (1998:79) - note that the WES pilot is not representative of the entire economy, only particular industries are selected in the pilot survey.

17 The establishment is first asked whether there "are any vacant positions currently unfilled" and if so, the respondent is asked to fill in a form specifying "The number of vacancies that, despite active recruitment, have been unfilled for less than four months or more than four months" --- for four broad occupation groups and "other". Note that this does not necessarily imply that the position is immediately available. Hence, the derived estimate ( $1 \%$ of employees or about $0.75 \%$ of the labour force) does not directly correspond to the stock of currently unemployed. As might be expected, most vacancies were for technical (35\%) and professional (28\%) occupations. 
This estimate is consistent with a 1995 survey of Quebec employers by HRDC/SQDM, which found 30,400 vacancies, equal to about $1.48 \%$ of paid employees (or around $1.14 \%$ of the labour force) at the time. However, in the Quebec data, only $17 \%$ of vacancies were considered to require a high level of skills, suggesting that a high proportion of vacancies represent normal turnover of workers among establishments (see Roy et al 1996:40) ${ }^{18}$.

If it is accepted that in a dynamic economy, some jobs are always coming empty and time may be required for them to be filled, one might want to distinguish analytically between "frictional" and "structural" vacancies. The corresponding empirical distinction is not easy to draw, but long duration vacancies for skilled labour may be a reasonable approximation. In the WES, only three vacancies in ten, or 0.3 per cent of the workforce, had been unfilled for four months or more "a relatively modest figure" (1998:79).

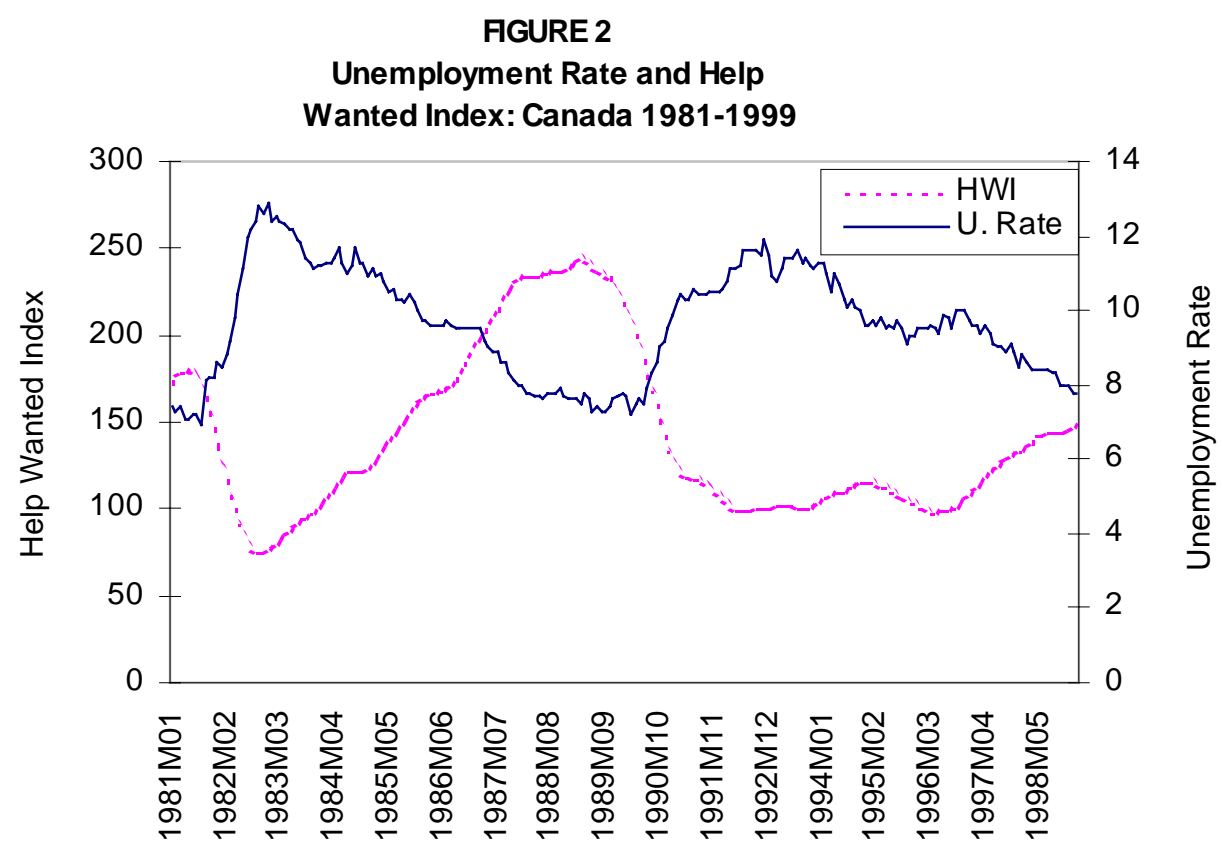

\subsection{The Help-Wanted Index/Unemployment Rate Relationship}

Statistics Canada has been producing a Help-Wanted Index since $1962,{ }^{19}$ which has frequently been relied on for evidence on vacancy trends. As Figure 2 illustrates, over time the Help-Wanted Index moves in almost perfect opposition to the unemployment rate.

18 A summary is available at http://www.qc.hrdc-drhc/socio-97/moueuvre/anglais/sect 5/sect 5.html.

19 Two statistical series have been published, the first from January 1962 to December 1988 and the second from January 1981 until the present day. Over the overlap period 1981 to 1988 the two series are nearly perfectly correlated --- see discussion in text below. 
Writing in 1991, Gera et al used the Help-Wanted Index (HWI) to argue that structural unemployment had risen in the 1980s. Using the correlation observed between direct measures of vacancies available from the Job Vacancy Survey and the HWI in the 1970s, they concluded that the Help-Wanted Index was a good proxy for available vacancies but that the relationship between it and the unemployment rate had changed significantly over the period 1966 to 1988. Figure 3 charts the relationship observed in monthly data between the Help-Wanted Index and the unemployment rate in Canada from January 1981 to December $1989 .{ }^{20}$

As Figure 3 indicates, there appears to have been a significant shift outwards in the Help-Wanted Index/unemployment rate relationship during the 1980s, which Gera et al saw as indicative of growing structural imbalances. ${ }^{21}$ They argued that growing inter-regional disparities and the scarring effect of increasingly prevalent long-term unemployment were responsible for this increase in structural imbalances. ${ }^{22}$

Whatever happened to the Help-Wanted Index/unemployment rate relationship in the 1980s, the 1990s have been very different. Figure 4 adds observations from January 1990 to February 1999 to the relationship already plotted in Figure 3. It is clear that the unemployment rate/HelpWanted Index relationship has shifted inwards during the 1990s, to such an extent that all of the outward shift of the 1980s has been reversed. By February 1999, the Help-Wanted Index/unemployment rate relationship was essentially back where it had been in $1981 .^{23}$

20 Gera et al (1991) used the old Help-Wanted Index series from 1966 to 1988, while this paper uses both the old as well as the new series, but Figure 2 in this paper is essentially identical to the top panel of their Chart 1, while Figure 3 replicates the bottom panel.

21 Gera et al (1991:44) --- they also rely heavily on the finding of a statistically significant time trend in regression estimates of the Help-Wanted Index/unemployment rate relationship.

22 Interestingly, they reject explanations based on generosity of the unemployment insurance system because "the evidence suggests that the UI system became less generous during the 1980s compared with the mid-1970s and that, as a result, ...the unemployment/vacancy relationship should therefore have shifted inward, not outward as it did in fact" (1991:22) Similarly, employment protection laws, minimum wages and unionization rates have the "wrong" trend to explain rising structural imbalances in the 1980s. They conclude "a job vacancy survey would assist policy makers in analyzing the growing mismatches between unfilled job vacancies and the attributes of the unemployed. ...The cost of providing such data would possibly not be more than the cost incurred by misguided policies pursued without the insights the job vacancy data might provide" (1991:45).

23 Which appears (see Gera et al (1991:6)) to be essentially identical to the late 1970s. 
FIGURE 3

The Help Wanted Index / Unemployment Rate Relationship:

Canada 1981-1989

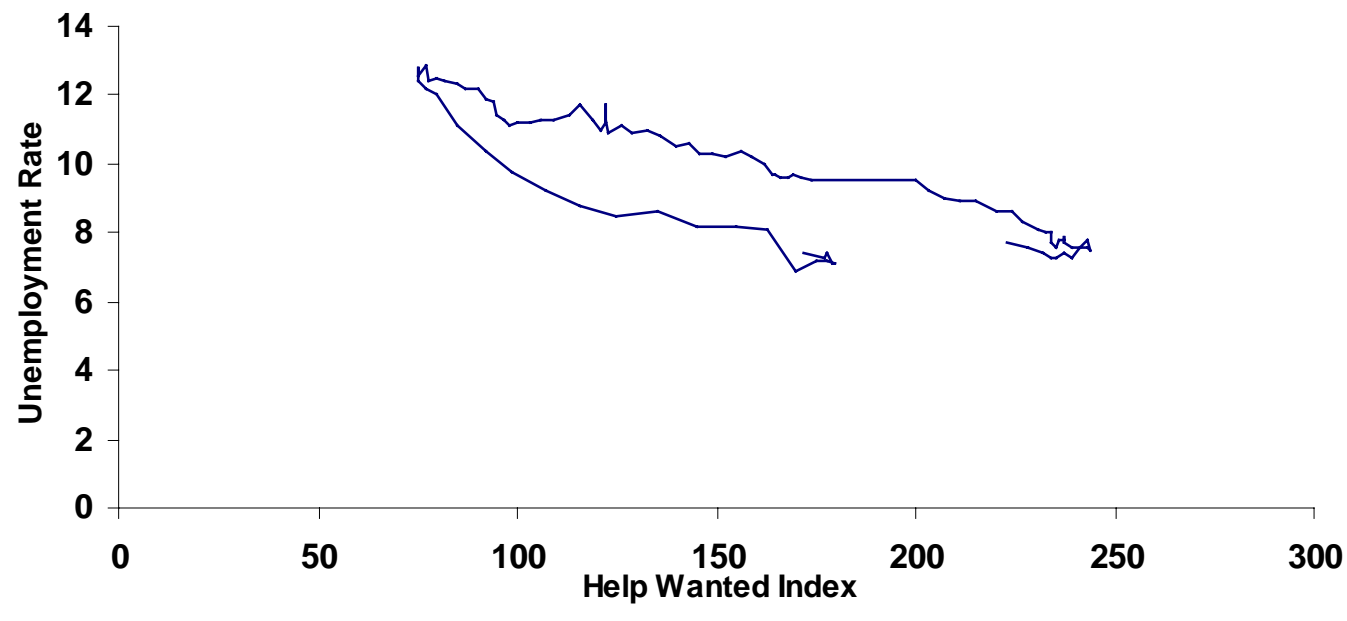

FIGURE 4

The Help Wanted Index / Unemployment Rate Relationship:

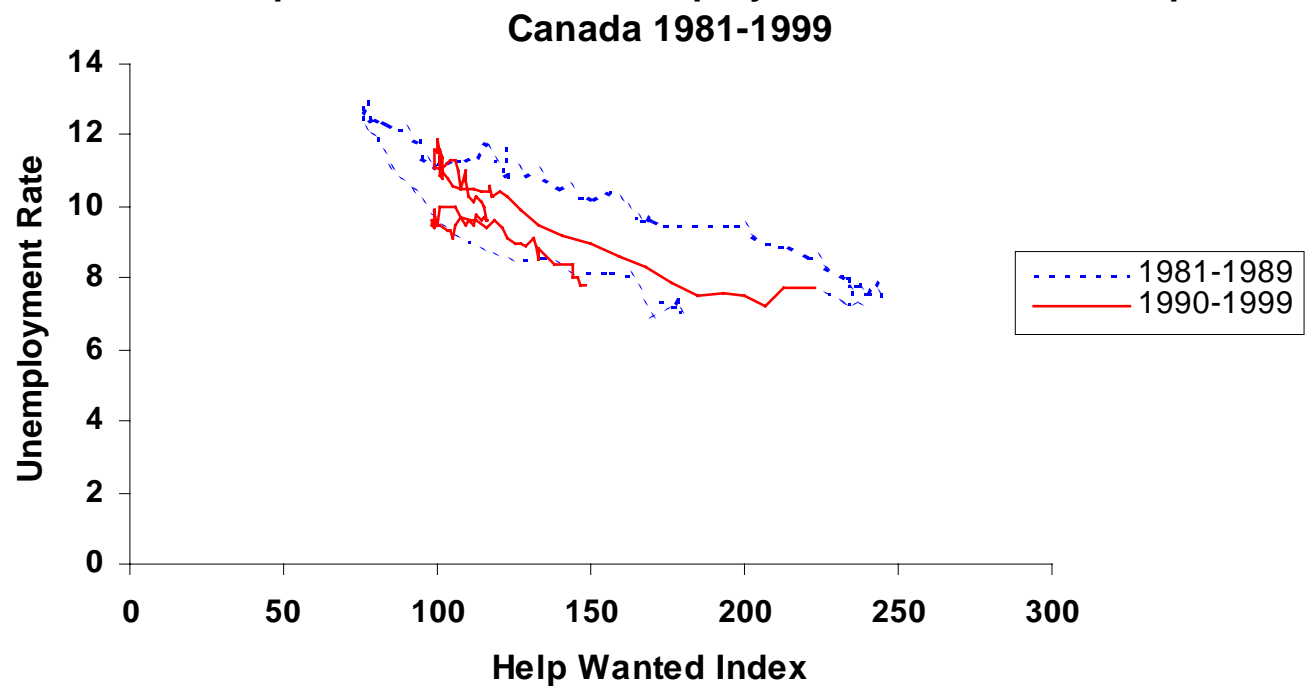


Although Figures 2 and 3 may be highly suggestive of a shift outwards, and then inwards, of the Beveridge curve, the original work of Gera et al (1991) relied heavily on the econometric finding of a positive and statistically significant time trend in estimates of the unemployment rate/HelpWanted Index relationship. We therefore have replicated their specification, and nested the hypothesis of a positive time trend in the 1980s within the broader specification that the time trend of the unemployment rate/Help-Wanted Index relationship may have shifted in the 1990s. Appendix C presents the full regressions, while the relevant time trends are presented in Table 1.

\section{TABLE 1}

Time-Trend in the Beveridge Curve, 1981:01-1999:03

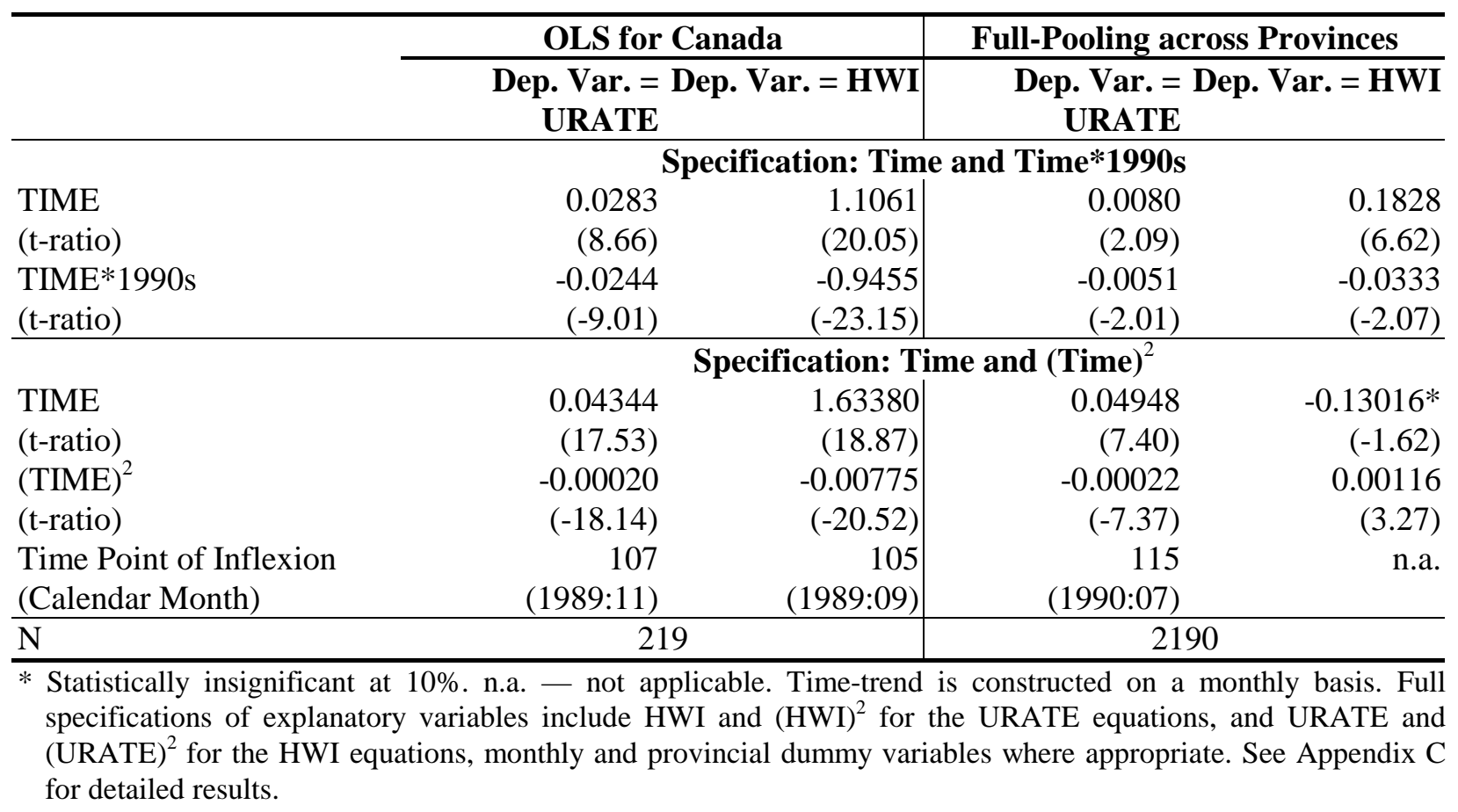

The top panel of Table 1 tests the hypothesis of a shift in the relationship during the 1990s by including an interaction term - (time)*(dummy if greater than 1990). Both the time trend and the interaction term are strongly statistically significant, indicating that the positive time trend of the 1980s was replaced by a negative trend in the 1990s. However, although useful as an indicator of a qualitative shift in the Beveridge curve time trend after 1990, this specification has the disadvantage of imposing a constant rate of change with time, which suddenly shifts (at a point in time specified by the researcher) to another constant rate of change. It would seem more reasonable to argue that if there is a change in the direction of shift of the Beveridge curve, that change would probably take the form of a gradual deceleration of outward shift, followed by a gradual inward shift. It would also seem reasonable to let the data specify the point in time at which an outward shift stops and an inward shift begins.

For these reasons (and because it fits better) we prefer the results summarized in the bottom panel of Table 1. We present estimates using both national and provincial level data, and using 
both ordinary least squares (OLS) and generalized least squares (GLS) estimation techniques on pooled cross-section time-series data, in order to assess the robustness of our conclusions. The quadratic specification nests the linear specification, and in fact the quadratic term is strongly statistically significant. A quadratic function of time can be evaluated both in the initial and final periods and solved for the implicit point of inflexion of the function. Notably, all but one of the quadratic functions estimated put the point of inflexion (i.e., the month in which the Beveridge Curve stopped shifting out and began to shift in) in a very narrow range between late 1989 and the middle of 1990.

\subsection{The Help-Wanted Index and the Number of Vacancies}

However, although trends in the Help-Wanted Index maybe a good indicator of trends in available jobs, the Help-Wanted Index is itself an index and not a direct measure of vacancies. The question remains: "How many vacancies are now available in the Canadian labour market?" Direct measurement of the number of vacancies in Canada ceased in 1978. However, Figures 3 and 4, and the regression results summarized in Table 1 indicate that by 1999 the matching efficiency of the Canadian labour market was approximately back to where it started in 1981. If so, then data from the Job Vacancy Survey of that period may still be highly relevant to predicting the level of vacancies in the Canadian labour market (see section 2.5 below).

An alternative methodology, proposed by Sharpe (1999) and the Canadian Labour Market and Productivity Centre (1988), is to use the Help-Wanted Index as a scaling factor which predicts the percentage change in vacancies, and to assume that vacancies were equal in number to the unemployed in a base year (1966). This methodology produces the estimate that unfilled vacancies amounted to about $2.3 \%$ of the labour force in 1998 , equivalent to $30 \%$ of total unemployment. ${ }^{24}$

This estimate of vacancies is effectively higher than the Branham Group's estimate (see section 2.1 above) of the 1998 vacancy rate in the information and telecommunications technology (ICT) industry, since it is expressed as a percentage of the labour force. Approximately $25 \%$ of the Canadian labour force is either unemployed or self employed. Hence, if one is to compare the Branham estimate of $2.87 \%$ as the vacancy rate (expressed as a percentage of employees) among high technology companies, the Sharpe estimate corresponds to $3.06 \%$ of paid employees. [Alternatively, if the estimate of the high technology vacancy rate is to be compared to the unemployment rate (which is calculated as a proportion of the labour force), the Branham estimate has to be scaled down to $2.15 \%$ of the labour force.]

However, it might easily be thought that it is unlikely that the vacancy rate in the rest of the economy is actually significantly higher than in the high technology sector.

24 See Torjman and Battle (1999:14). 


\subsection{The Vacancy Rate/Help-Wanted Index Relationship}

If changes in the Help-Wanted Index are a good proxy for changes in the vacancy rate, the vacancy data from the Job Vacancy Survey (JVS) may be useful for establishing the level of vacancies. There are three steps to our approach: (1) since the methodology of the Help-Wanted Index now in use differs somewhat from that in use when the JVS was conducted, we establish the empirical relationship between the "old" and the "new" Help-Wanted Index (HWI); (2) we estimate the relationship between vacancy rates derived from the 1971-1978 Job Vacancy Survey (JVS) and the old HWI [controlling for seasonal variations and regional differences, the labour force participation rate and the employment rate]; (3) we predict vacancy rates in the 1990s.

\subsubsection{The "Old" and the "New" Help-Wanted Index}

The Canadian Help-Wanted Index (HWI) is patterned after an index developed and published by the Conference Board in the United States. The Department of Finance first released a Canadian index in 1973. Statistics Canada assumed responsibility for its construction and publication since 1974. Our analysis involves using both series - the "old" series covering 1962-1988 and the "new" series covering 1981 onwards.

The old HWI was constructed by measuring the column space of job advertisements published under the classified section of 18 major metropolitan area newspapers for 17 metropolitan areas (see appendix B). The measured column space for any given month was then compared to the respective average column space in the base year and adjusted by the appropriate population weights. Data were collected one Saturday a month — specifically, the Saturday corresponding to the reference week for the Labour Force Survey, usually the week which contains the 15th day of the month. When the ad space was measured, care was taken to exclude special headings and materials not pertaining to help-wanted advertisements. Ads which did not appear in the classified section [sections titled "careers" or "opportunities", ads for "position wanted", or ads for newspaper carriers] were excluded.

Since 1981, Statistics Canada has published another series, the "new" HWI. The new index is constructed using the number of help-wanted advertisements in the classified section of the newspaper instead of measuring the column space. This eliminates the distortions caused by varying sizes of help-wanted ads across different newspapers at any given particular point in time or the changing format and layout of the classified section of newspapers over time. The number of metropolitan areas covered also increased from 17 to 20, and the number of newspapers covered rose from 18 to 22 . This improves the population representation both nationally and regionally. ${ }^{25}$

Since it is the old HWI which overlaps the Job Vacancy Survey, a natural question arises: How do the two series compare to each other in light of the methodological differences? Fortunately,

25 Other differences include that the data in the new series are trend-cycle estimates --- this removes the irregular component from a time-series and thereby smoothes the seasonally adjusted data, and that estimates for the three most recent months are preliminary --- subject to revisions. Details on the construction of the new series are provided in Statistics Canada, Help-Wanted Index 1988, Catalogue 71-204. 
the two series overlap between January 1981 and December 1988 and data constructed using both the old (measuring the column space of help-wanted ads) and the new (counting the number of help-wanted ads) methods are available for these 8 years. Previous research shows that the two series follow each other very closely at the national level in spite of the differing methodology. Shifting the two series from a lag of up to five months to a lead of up to eight months, HaggarGuenette (1988) finds the cross-correlation coefficient between the two series ranges from 0.86 to 0.99 . When the two series are related to the employment-population ratio or the unemployment rate, very similar cross-correlation coefficients are found with respect to each of the two series.

To further investigate the relationship between the two series, we apply a common base-year to the two series - adjusting the new series to the 1981 base. ${ }^{26}$ Our analysis at the national level as well as the regional level confirms that the two series indeed track each other very closely.

- The monthly raw data at the national level show that the two series follow nearly an identical pattern (Figure 5), with a correlation coefficient of 0.98 .

- When the old HWI is regressed on the re-based new HWI without a constant term, we obtain a coefficient of 0.96 at the national level with t-ratio $=82$ (number of observations $=96$ ).

- When the monthly data are pooled across the five regions and the old HWI is regressed on the re-based new HWI without a constant term, OLS produces a coefficient of 0.93 with tratio $=137$ while full-pooling GLS produces a coefficient of 0.97 with t-ratio $=65$ (number of observations $=480$ ).

FIGURE 5

The Old vs the New Help-Wanted Index, Canada, 1981:01-1988:12

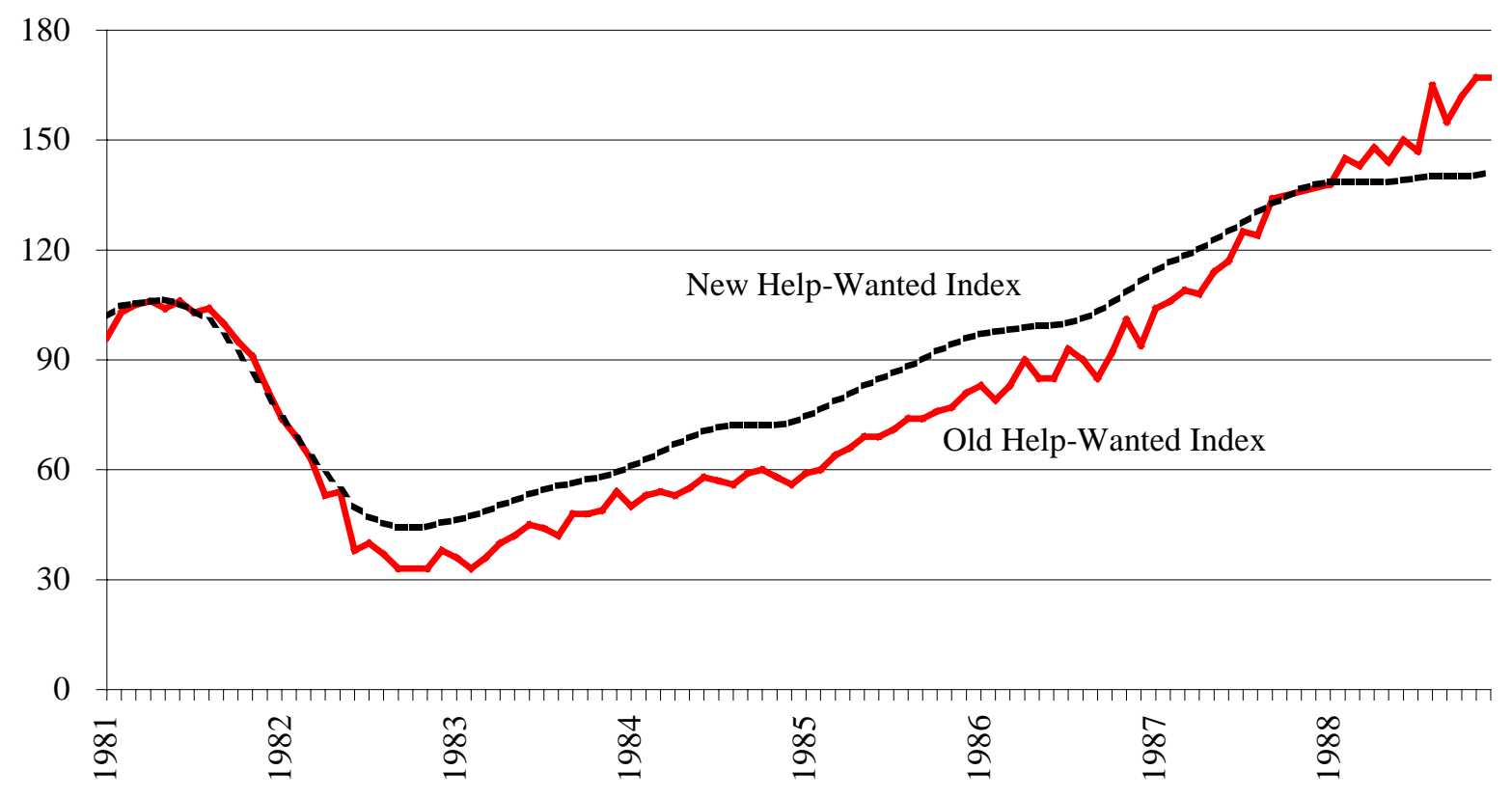

26 In the original data, the base year is 1981 for the old series and 1996 for the new series. 


\subsubsection{Modelling the Vacancy Rates}

The second step is to estimate the relationship between job vacancies derived from the Job Vacancy Survey (JVS) and the old HWI (as well as a set of labour market indicators) from 1971 to 1978. Conditioned by the availability of the job vacancy rates (quarterly data) and the old HWI (regional data), we pool the quarterly data across the five regions and estimate two full-pooling GLS models:

1) the vacancy rate as a function of the old HWI, the participation rate (Part. Rate) and the employment rate (Emp. Rate), ${ }^{27}$ controlling for quarterly (seasonal) as well as regional variations;

2) the vacancy rate as a function of the old HWI alone, again controlling for quarterly as well as regional variations.

These models are estimated with and without a dummy variable on time trend - constructed on a quarterly basis - as an additional explanatory variable, which results in a total of four specifications estimated.

The Canadian JVS began operation in 1971 and was discontinued after 1978. The JVS was conducted twice a month through a sample survey among employers representing approximately $90 \%$ of total employment, covering all industrial sectors except agriculture, fishing and trapping, domestic service and the non-civilian component of public administration and defence. A feature of the sample design was the rotation of the sample to avoid an undue reporting burden on the survey respondents. The sample was in the form of two replicated subsamples to provide simple variance estimates based on the differences between the two subsamples. The population of job vacancy reporting units (JVRU's) was divided into five sectors: ES - 1 consisting of business establishments with 20 or more employees; ES - 2 consisting of business establishments with 19 or fewer employees; educational and other institutions; federal and provincial governments; and municipal governments. ${ }^{28}$

27 For the HWI, a quarterly average is calculated from the monthly data; since 1976, the participation rate and the employment rate are calculated from data drawn from Statistics Canada's CANSIM database. Prior to 1976, these rates are constructed using data drawn from Statistics Canada's Historical Labour Force Statistics 1993, Catalogue 71-201. Because the original data are at the provincial level but regional data are needed in our estimation, each series on population, labour force and employment is aggregated to regional level and the rates are calculated accordingly. In other words, the labour force participation rate and the employment rate used in our analysis are provincially weighted instead of simple provincial averages. Quarterly data are then generated by taking the regional monthly averages.

28 Within each sector, the population of JVRU's was stratified by location, industry and size. Within each stratum, JVRU's were assigned at random to a given number of panels and within a panel to two subpanels. The subpanel designations controlled the sample replication mentioned earlier. Details of the sample design are provided in Statistics Canada, Annual Report on Job Vacancies 1978, Catalogue 71-203. Detailed discussions of conceptual and definitional issues are given in Ostry and Sunter (1970). In the JVS, job vacancies were grouped into three categories: all vacancies --- for full-time, casual, part-time, seasonal and temporary jobs; vacancies for full-time jobs --- for jobs with a minimum duration of four full standard work weeks or one full standard work month; longer-term vacancies --- for full-time jobs which had not been filled for one month or longer. We use the category of all vacancies in our analysis. The JVS measured unfilled vacancies at six points in time throughout the quarter which were averaged to provide quarterly estimates. A short reference period (one day) was selected 
Job vacancies in the JVS were defined analogously to unemployment - i.e., position openings had to meet four criteria: 1) available immediately; 2) for which employers had undertaken, within four weeks prior to the reference date, some specific recruiting action to fill the positions [e.g., advertised, contacted Canada Manpower Centres, interviewed walk-ins]; 3) vacant for the entire reference day; and 4) open to people outside the establishment. Certain types of position openings were thus excluded: i) openings that had a future starting date and hence were not "immediately available"; ii) openings for which no recruiting action was undertaken or recruiting action ceased four weeks prior to the reference day; iii) openings that could be filled immediately from employers' or unions' waiting list and thus were not "vacant for the entire reference day"; iv) positions that were open only to employees of the firm (either working or on temporary layoff) and hence not "open to people outside the establishment".

Table 2 reports summary statistics on key variables and the full-pooling GLS regression results on the above-mentioned four specifications of the vacancy rate model from the first quarter of 1971 to the last quarter of $1978 .{ }^{29}$ Other things equal, job vacancy rates generally rise with the help-wanted index and the employment rate but decline when labour force participation is higher. Seasonality is also evident - vacancy rates are higher in the spring and summer (2nd and 3rd quarter). There are also regional variations - vacancy rates are lower in Atlantic Canada and Quebec than in Ontario, but higher in the Prairie provinces and British Columbia. When the employment rate and labour force participation rate are dropped as explanatory variables, similar results are obtained regarding the association between vacancy rates and the help-wanted index.

to make it easier for respondents to recall vacancies. Thus, the estimates were best interpreted as an approximation of the general level of vacancies at any given day in the quarter. Estimates of vacancies were obtained by multiplying totals of vacancies in different response categories in each stratum by appropriate weights for whatever the desirable level (e.g., Canada as a whole, a specific province, a specific industry, or a specific occupation). Job vacancy rates were then obtained by expressing the number of vacancies per 1,000 existing jobs. A detailed description of the estimation procedure is provided in Statistics Canada, The Canadian Job Vacancy Survey: Technical Appendix, Catalogue 71-521.

29 We have also performed OLS regressions at the national as well as pooled-regional level and obtained similar results. Note that in column 4 of Table 2, the statistically significant negative co-efficient on the time trend would imply that the vacancy rate conditional on the HWI, is trending down over time. This would imply that our vacancy rate estimate reported in the second panel of Tables 3 and 4 are over-estimates. 
TABLE 2

Summary Statistics and Full-Pooling GLS Regression Results on Vacancy Rates

\begin{tabular}{|c|c|c|c|c|}
\hline \multirow[b]{2}{*}{ Variable } & \multicolumn{4}{|c|}{ Summary Statistics } \\
\hline & & \multicolumn{2}{|c|}{ Mean } & Standard Deviation \\
\hline Vacancy Rate & & \multicolumn{2}{|c|}{7.681} & 3.710 \\
\hline Help-Wanted Index & & \multicolumn{2}{|c|}{73.454} & 29.558 \\
\hline LF Part. Rate & & \multicolumn{2}{|c|}{59.566} & 4.507 \\
\hline Employment Rate & & \multicolumn{2}{|c|}{92.804} & 2.342 \\
\hline \multirow[t]{2}{*}{$\mathrm{N}$} & \multicolumn{4}{|c|}{160} \\
\hline & \multicolumn{4}{|c|}{ Regression Results (Dep. Var. = Vacancy Rate) } \\
\hline Explanatory Variable & $\begin{array}{r}\text { Coefficient } \\
\text { (1) }\end{array}$ & $\begin{array}{r}\text { Coefficient } \\
\text { (2) }\end{array}$ & $\begin{array}{r}\text { Coefficient } \\
\text { (3) }\end{array}$ & $\begin{array}{r}\text { Coefficient } \\
(4)\end{array}$ \\
\hline Help-Wanted Index & $\begin{array}{r}0.0732 \\
(6.01)\end{array}$ & $\begin{array}{r}0.0744 \\
(5.97)\end{array}$ & $\begin{array}{r}0.0579 \\
(3.29)\end{array}$ & $\begin{array}{r}0.0818 \\
(5.78)\end{array}$ \\
\hline LF Part. Rate & $\begin{array}{r}-0.3598 \\
(-2.99)\end{array}$ & $\begin{array}{r}-0.1416 \\
(-0.84)\end{array}$ & & \\
\hline Employment Rate & $\begin{array}{r}0.8423 \\
(6.47)\end{array}$ & $\begin{array}{r}0.6996 \\
(4.13)\end{array}$ & & \\
\hline Q2 & $\begin{array}{r}0.7393 \\
(1.58)\end{array}$ & $\begin{array}{r}0.4739 \\
(1.00)\end{array}$ & $\begin{array}{r}0.9885 \\
(3.18)\end{array}$ & $\begin{array}{r}0.9926 \\
(3.01)\end{array}$ \\
\hline Q3 & $\begin{array}{r}1.4942 \\
(2.30)\end{array}$ & $\begin{array}{r}1.0065 \\
(1.49)\end{array}$ & $\begin{array}{r}1.6042 \\
(4.42)\end{array}$ & $\begin{array}{r}1.7240 \\
(4.53)\end{array}$ \\
\hline Q4 & $\begin{array}{r}-0.5954 \\
(-1.31)\end{array}$ & $\begin{array}{r}-0.6101 \\
(-1.35)\end{array}$ & $\begin{array}{r}0.1024 \\
(0.32)\end{array}$ & $\begin{array}{r}0.2805 \\
(0.82)\end{array}$ \\
\hline Time & & $\begin{array}{r}-0.0718 \\
(-1.48)\end{array}$ & & $\begin{array}{r}-0.1979 \\
(-5.80)\end{array}$ \\
\hline Atlantic & $\begin{array}{r}-2.7520 \\
(-1.60)\end{array}$ & $\begin{array}{r}-0.9978 \\
(-0.52)\end{array}$ & $\begin{array}{r}-2.0370 \\
(-1.00)\end{array}$ & $\begin{array}{r}-2.3332 \\
(-2.91)\end{array}$ \\
\hline Quebec & $\begin{array}{r}-3.5989 \\
(-2.48)\end{array}$ & $\begin{array}{r}-2.8402 \\
(-1.89)\end{array}$ & $\begin{array}{r}-3.6179 \\
(-1.28)\end{array}$ & $\begin{array}{r}-4.1992 \\
(-2.88)\end{array}$ \\
\hline Prairie & $\begin{array}{r}2.4352 \\
(2.20)\end{array}$ & $\begin{array}{r}2.7115 \\
(2.39)\end{array}$ & $\begin{array}{r}2.6858 \\
(1.35)\end{array}$ & $\begin{array}{r}3.5515 \\
(2.78)\end{array}$ \\
\hline $\mathrm{BC}$ & $\begin{array}{r}1.8009 \\
(2.63)\end{array}$ & $\begin{array}{r}2.1327 \\
(3.04)\end{array}$ & $\begin{array}{r}0.6393 \\
(0.38)\end{array}$ & $\begin{array}{r}1.3169 \\
(1.73)\end{array}$ \\
\hline Constant & $\begin{array}{r}-54.4930 \\
(-3.36)\end{array}$ & $\begin{array}{r}-53.6010 \\
(-3.19) \\
\end{array}$ & $\begin{array}{r}2.5237 \\
(1.59)\end{array}$ & $\begin{array}{r}4.3071 \\
(3.76) \\
\end{array}$ \\
\hline
\end{tabular}

Note: Asymptotic t-ratios are given in parentheses.

Figure 6 charts the raw vacancy rate against the estimated ones using the regression results evaluated at the national level and shows that both specifications (HWI alone or along with Labour Force participation rate and employment rate) indeed model the vacancy rate quite well (assuming no downward time trend). 
FIGURE 6

Raw vs Estimated Vacancy Rates, Canada, 1971:I-1978:IV

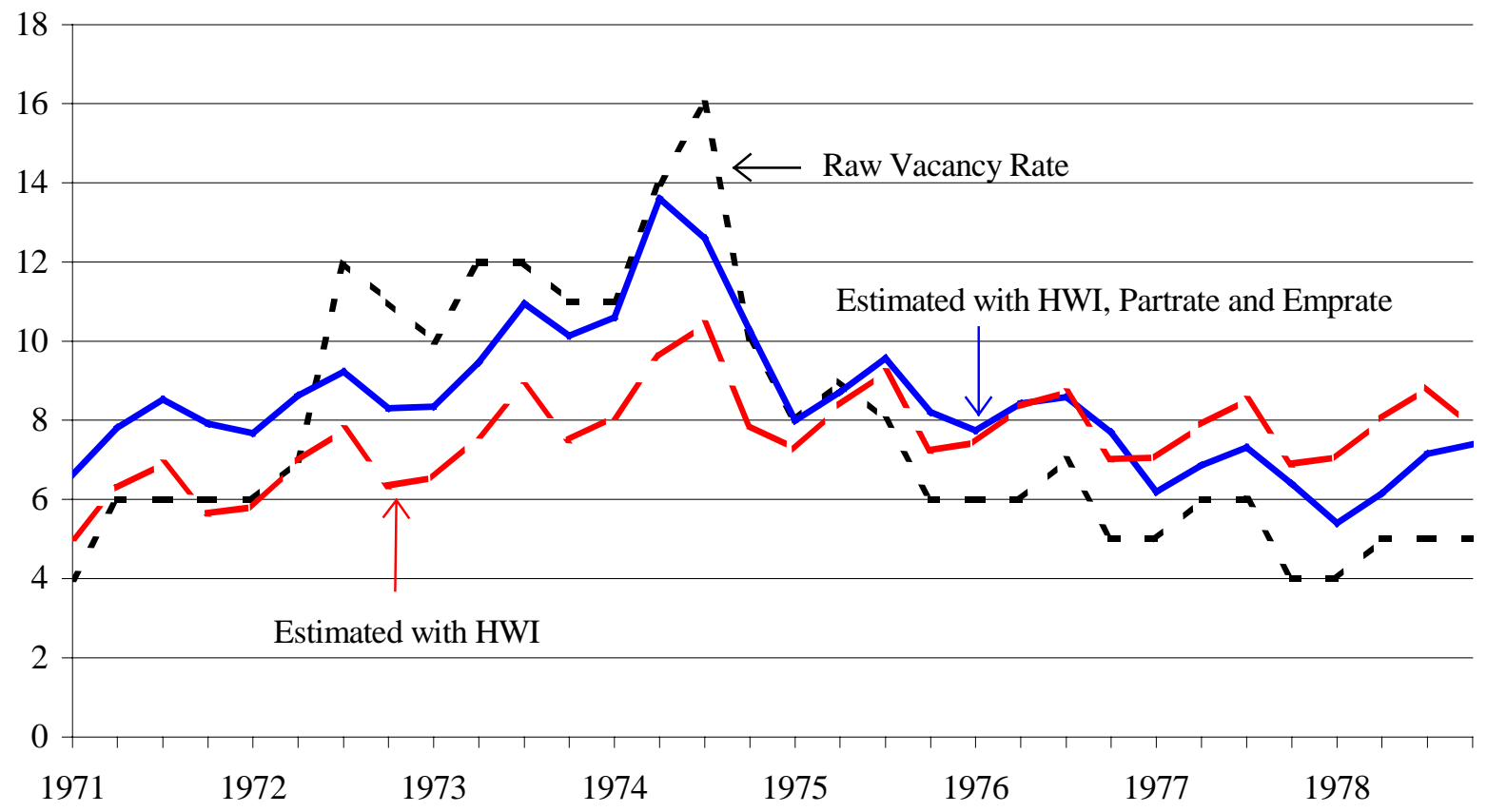

\subsubsection{Predicting Job Vacancies for the 1980s and 1990s}

The third and final step is to use existing data on the new HWI, labour force participation rates and employment rates to predict job vacancies for the 1980s and 1990s. More specifically, the two specifications of the vacancy rate model reported in Columns 1 and 3 of Table 2 are: ${ }^{30}$

(1) VACANCYRATE $=-54.493+0.0732 *$ OLDHWI-0.3598*PARTRATE $+0.8423 *$ EMPRATE + $0.7393 * \mathrm{Q} 2+1.4942 * \mathrm{Q} 3$; and

(2) VACANCYRATE $=2.5237+0.0579 * \mathrm{OLDHWI}+0.9885 * \mathrm{Q} 2+1.6042 * \mathrm{Q} 3$.

Regressing the old HWI on the re-based new HWI without a constant term using a full-pooling GLS regression on the pooled monthly data for 1981-1988 across the five regions gives us the following relationship:

30 While the time dummy is statistically significant in Column 4, it is not significant in Column 2. Results on the specifications with the time dummy as an additional explanatory variable are not used in our prediction. Since our predictions are evaluated at the national level, regional dummy variables do not enter the prediction function. 
(3) OLDHWI $=0.9662 *$ RBNEWHWI $(\mathrm{t}=65.2, \mathrm{~N}=480)$.

To get the conditional expectation of the vacancy rate, we substitute Equation 3 into Equations 1 and 2, which gives us:

(4) VACANCYRATE $=-54.493+0.0732 *(0.9662 *$ RBNEWHWI $)+$

$$
\begin{aligned}
& 0.3598 * \mathrm{PARTRATE}+0.8423 * \text { EMPRATE}+ \\
& 0.7393 * \mathrm{Q} 2+1.4942 * \mathrm{Q} 3 \text {; and }
\end{aligned}
$$

(5) VACANCYRATE $=2.5237+0.0579 *(0.9662 * \mathrm{RBNEWHWI})+0.9885 * \mathrm{Q} 2+1.6042 * \mathrm{Q} 3$.

Table 3 reports the fitted vacancy rates using prediction equations 4 and 5 for Canada for 1981:I1998:IV. ${ }^{31}$

TABLE 3

Predicted Job Vacancies per 1,000 Employment, Canada, 1981:I-1998:IV

\begin{tabular}{lrrrrr|rrrrr}
\hline & \multicolumn{4}{c|}{ Predicted Vacancies (1) } & \multicolumn{5}{c}{ Predicted Vacancies (2) } \\
\cline { 2 - 10 } & I & II & \multicolumn{1}{c|}{ III } & \multicolumn{2}{c|}{ IV Average } & I & II & III & IV & Average \\
\hline 1981 & 7.1 & 8.2 & 8.4 & 5.9 & 7.4 & 8.3 & 9.4 & 9.7 & 7.3 & 8.7 \\
1982 & 3.4 & 2.0 & 1.1 & -0.4 & 1.5 & 6.4 & 6.6 & 6.7 & 5.0 & 6.2 \\
1983 & -1.4 & 0.2 & 2.0 & 1.7 & 0.6 & 5.2 & 6.4 & 7.2 & 5.8 & 6.1 \\
1984 & 0.8 & 2.0 & 3.3 & 2.5 & 2.2 & 6.0 & 7.4 & 8.2 & 6.6 & 7.0 \\
1985 & 1.8 & 3.5 & 5.1 & 4.7 & 3.8 & 6.8 & 8.1 & 9.1 & 7.8 & 7.9 \\
1986 & 4.1 & 5.4 & 6.5 & 6.2 & 5.6 & 8.0 & 9.1 & 9.8 & 8.6 & 8.9 \\
1987 & 5.5 & 7.4 & 9.0 & 9.0 & 7.7 & 9.0 & 10.4 & 11.4 & 10.2 & 10.2 \\
1988 & 8.4 & 9.6 & 10.2 & 9.6 & 9.4 & 10.3 & 11.3 & 12.0 & 10.4 & 11.0 \\
1989 & 8.8 & 9.7 & 10.5 & 9.2 & 9.6 & 10.5 & 11.5 & 11.9 & 10.1 & 11.0 \\
1990 & 7.6 & 7.9 & 7.0 & 4.3 & 6.7 & 9.6 & 9.9 & 9.7 & 7.2 & 9.1 \\
1991 & 1.7 & 2.5 & 3.3 & 2.3 & 2.4 & 6.6 & 7.4 & 7.9 & 6.2 & 7.0 \\
1992 & 0.6 & 1.3 & 1.9 & 1.1 & 1.2 & 5.9 & 6.8 & 7.4 & 5.8 & 6.5 \\
1993 & 0.7 & 1.4 & 2.2 & 1.7 & 1.5 & 5.9 & 6.9 & 7.5 & 5.9 & 6.5 \\
1994 & 1.0 & 2.4 & 3.7 & 3.5 & 2.7 & 6.1 & 7.1 & 7.9 & 6.4 & 6.9 \\
1995 & 2.6 & 3.6 & 4.2 & 3.5 & 3.5 & 6.3 & 7.2 & 7.6 & 5.9 & 6.8 \\
1996 & 2.2 & 3.1 & 3.7 & 3.1 & 3.0 & 5.8 & 6.8 & 7.4 & 6.0 & 6.5 \\
1997 & 2.9 & 4.2 & 5.4 & 5.1 & 4.4 & 6.3 & 7.5 & 8.3 & 6.9 & 7.3 \\
1998 & 4.5 & 5.8 & 6.6 & 6.0 & 5.8 & 7.0 & 8.2 & 8.9 & 7.3 & 7.9 \\
\hline
\end{tabular}

Note: Vacancies (1) predicted per Equation 4; vacancies (2) predicted per Equation 5.

The predicted vacancy rates in Table 3 are expressed as fractions of total employment. But we are interested in what would have happened to the unemployment rate if all vacancies were filled. Therefore, it is more useful to express vacancies as a fraction of the labour force (which is the denominator for the unemployment rate) - to be comparable to the currently unemployed. Table

31 As mentioned earlier, quarterly averages are calculated from the monthly data, and because we are predicting at the original level, each series on population, labour force and employment is aggregated to the regional level from the provincial data and the rates are calculated accordingly --- that is, the labour force participation rate and the employment rate used in our predictions are provincially weighted instead of simple provincial averages. 
4 hence reports predicted job vacancies as a fraction of the labour force. Since the Job Vacancy Survey did not cover the self-employed sector, the appropriate factor used to adjust the predictions should be the paid-employment rate for the appropriate year (e.g., 75\% of the labour force in 1998).

TABLE 4

Predicted Job Vacancies per 1,000 Labour Force, Canada, 1981:I-1998:IV

\begin{tabular}{|c|c|c|c|c|c|c|c|c|c|c|}
\hline & \multicolumn{5}{|c|}{ Predicted Vacancies (1) } & \multicolumn{5}{|c|}{ Predicted Vacancies (2) } \\
\hline & I & II & III & IV & Average & I & II & III & IV & Average \\
\hline 1981 & 5.6 & 6.6 & 6.8 & 4.7 & 5.9 & 6.6 & 7.6 & 7.9 & 5.8 & 7.0 \\
\hline 1982 & 2.7 & 1.5 & 0.9 & -0.3 & 1.2 & 4.9 & 5.1 & 5.1 & 3.8 & 4.7 \\
\hline 1983 & -1.0 & 0.1 & 1.6 & 1.3 & 0.5 & 3.8 & 4.8 & 5.5 & 4.4 & 4.6 \\
\hline 1984 & 0.6 & 1.6 & 2.6 & 1.9 & 1.7 & 4.5 & 5.6 & 6.3 & 5.0 & 5.4 \\
\hline 1985 & 1.3 & 2.6 & 4.0 & 3.6 & 2.9 & 5.1 & 6.2 & 7.0 & 6.0 & 6.1 \\
\hline 1986 & 3.1 & 4.2 & 5.1 & 4.9 & 4.3 & 6.1 & 7.0 & 7.7 & 6.7 & 6.9 \\
\hline 1987 & 4.3 & 5.8 & 7.1 & 7.1 & 6.1 & 6.9 & 8.1 & 9.0 & 8.0 & 8.0 \\
\hline 1988 & 6.6 & 7.6 & 8.1 & 7.6 & 7.5 & 8.0 & 8.9 & 9.5 & 8.3 & 8.7 \\
\hline 1989 & 6.9 & 7.8 & 8.4 & 7.3 & 7.6 & 8.3 & 9.2 & 9.6 & 8.1 & 8.8 \\
\hline 1990 & 6.0 & 6.2 & 5.5 & 3.3 & 5.3 & 7.5 & 7.9 & 7.6 & 5.6 & 7.2 \\
\hline 1991 & 1.3 & 1.9 & 2.5 & 1.7 & 1.9 & 5.0 & 5.7 & 6.1 & 4.7 & 5.4 \\
\hline 1992 & 0.5 & 1.0 & 1.5 & 0.8 & 0.9 & 4.4 & 5.1 & 5.6 & 4.4 & 4.9 \\
\hline 1993 & 0.5 & 1.0 & 1.7 & 1.3 & 1.1 & 4.4 & 5.1 & 5.6 & 4.5 & 4.9 \\
\hline 1994 & 0.8 & 1.8 & 2.8 & 2.7 & 2.0 & 4.5 & 5.4 & 6.0 & 4.9 & 5.2 \\
\hline 1995 & 1.9 & 2.7 & 3.2 & 2.7 & 2.6 & 4.7 & 5.5 & 5.9 & 4.5 & 5.1 \\
\hline 1996 & 1.6 & 2.3 & 2.8 & 2.3 & 2.3 & 4.3 & 5.1 & 5.6 & 4.5 & 4.9 \\
\hline 1997 & 2.1 & 3.1 & 4.0 & 3.8 & 3.3 & 4.6 & 5.6 & 6.2 & 5.2 & 5.4 \\
\hline 1998 & 3.4 & 4.4 & 5.0 & 4.6 & 4.3 & 5.2 & 6.2 & 6.7 & 5.6 & 5.9 \\
\hline
\end{tabular}

Note: Vacancies (1) predicted per Equation 4; vacancies (2) predicted per Equation 5. Both series are adjusted by the paid-employment rate. 
TABLE 5

Vacancy Rate Estimates

\begin{tabular}{|c|c|c|c|c|}
\hline Author/Date & Methodology & Sample Frame & $\begin{array}{l}\text { Vacancies/ } \\
\text { Employees }\end{array}$ & $\begin{array}{r}\text { Vacancies/ } \\
\text { LF }\end{array}$ \\
\hline $\begin{array}{l}\text { Branham Group } \\
1998\end{array}$ & $\begin{array}{r}\text { Survey - } 34 \text { firm } \\
\text { respondents }\end{array}$ & $\begin{array}{r}\text { Leading ICT firms } \\
{[\mathrm{ICT}=2.7 \% \text { of labour }} \\
\text { force }]\end{array}$ & $2.87 \%$ & $2.15 \% *$ \\
\hline Sharpe 1999 & $\begin{array}{r}\text { Assume vacancies = } \\
\text { unemployed in } \\
\text { 1966; update by } \\
\text { HWI }\end{array}$ & Canadian labour force & & $2.3 \%$ \\
\hline $\begin{array}{l}\text { Statistics Canada } \\
\text { Workplace and } \\
\text { Employee Survey } \\
1996\end{array}$ & $\begin{array}{l}\text { Stratified random } \\
\text { sample of firms - } \\
748 \text { respondents }\end{array}$ & $\begin{array}{r}\text { Cross-section of } \\
\text { Canadian firms (see } \\
\text { Appendix D) }\end{array}$ & $1 \%$ & $0.75 \% *$ \\
\hline $\begin{array}{l}\text { Osberg and Lin } \\
1999\end{array}$ & $\begin{array}{r}\text { Scale up Job } \\
\text { Vacancy Survey by } \\
\text { Help-Wanted Index } \\
\end{array}$ & $\begin{array}{r}\text { Canadian paid } \\
\text { employees }\end{array}$ & $0.58 \%-0.79 \%$ & $\begin{array}{r}0.43 \%- \\
0.59 \%\end{array}$ \\
\hline HRDC/SQDM 1995 & Survey & $\begin{array}{r}\text { Quebec employers } \\
\text { (with } 5 \text { or more } \\
\text { employees) }\end{array}$ & $1.48 \%$ & $1.14 \%$ \\
\hline
\end{tabular}

* Vacancy rate originally calculated as percentage of paid workforce - scaled down by a factor of 0.75 to reflect paid employees as a percentage of the total labour force.

\section{Conclusion}

One possible conclusion from all this is that the concept of structural unemployment is unavoidably bogus - that vacancies are too problematic in conception and too difficult to measure empirically for total "available jobs" ever to be measured accurately. If this is so, then the structural component of unemployment cannot be measured independently of the aggregate total of unemployment which the structural mismatch hypothesis seeks to explain, and the argument becomes clearly circular. In this case, the term "structural unemployment" should be banished from the economist's vocabulary, to be replaced by the more accurate terms "predicted unemployment" (when the expected level of unemployment conditional on an estimated structural relationship is meant) or "long term average unemployment" (when that is meant).

However, it is not clear why a "vacancy" on the firm side of the labour market is inherently more difficult to measure than "unemployment" on the worker side of the market. After all, since firms typically employ multiple workers, the average firm is more often engaged in the search process than the average worker. ${ }^{32}$ On both sides of the market, an unfilled match is costly and market participants have an incentive to recognize and correct the situation - so firms do in general

32 For both firms and workers, explicit search may not be needed to initiate a job match. Workers may move directly from not in labour force status to employment, if approached directly by an employer (see Osberg, 1993) and firms may similarly create a vacancy for a promising worker (see Granovetter, 1974). However, both firms and workers can also identify when they are actively searching for a match. 
know when vacancies exist. Although for both workers and firms there may be some ambiguity in estimating when search is serious, and at what wage rate a match would be acceptable, there does not seem to be any grounds for a presumption that employers are less capable or less honest than individual workers in answering surveys.

In fact, vacancies are routinely measured in some countries. In a number of countries, administrative data on job placement services are used, since in some contexts such data provide a more comprehensive picture of the labour market than would be the case in Canada. In the Netherlands, for example, employers have also been surveyed regularly since 1973 (with questionnaire revisions in 1980 and 1988) — see van Bastelaer and Laan (1994).

The measurement of vacancies is important for microeconomic labour market policy design and macroeconomic policy settings. One conclusion is that perhaps it is time to get some better information on Canadian vacancies. The Workplace and Employee Survey will be providing some information in persistent vacancies, and shall increase our knowledge in this area. As noted in section 2.1, statistics on "labour shortages" are now being used in the policy debate, but the problem is that these are often very poor statistics, whose implications may be quite misleading.

The key idea underlying the concept of "structural unemployment" in labour economics is that some unemployed people are unable to accept available jobs because they do not have the right skills, or are in the wrong place. This paper has therefore looked for evidence on the number of unfilled vacancies in the Canadian economy. Since some vacancies are due to normal turnover, and are quickly filled, the number of vacancies must be seen as an upper bound on the extent of structural unemployment — but the vacancy rate is not high, in any event.

Available surveys of the Quebec and Canadian labour markets in 1995 and 1996 put the vacancy rate at about $1.14 \%$ and $0.75 \%$ of the labour force. This paper has presented evidence that the Canadian Beveridge Curve has shifted in, during the 1990s, after shifting out during the 1980s. Evidence from the Job Vacancy Survey is therefore relevant. If projected to the 1990s, that evidence indicates the vacancy rate is $0.4 \%$ to $0.6 \%$ of the labour force.

In a dynamic economy, some sectors are always growing faster than others, and have the growing pains to match. Although the "high technology" sector may have a vacancy rate of as much as $2.8 \%$ of employees (equivalent to $2.2 \%$ of labour force), this sector is very small as a proportion of total employment and its vacancy rate is certainly much higher than that in the economy as a whole.

Turning back to the question posed as the title of the paper, "how much of Canada's unemployment is structural"? At the time of writing (April 1999), the best evidence is that less than one-eighth of the national unemployment rate could be due to structural mismatch between the skills demanded in available jobs and the skills possessed by the unemployed. 


\section{Appendix A Definitions of Structural Unemployment}

Although the term "structural unemployment" appears in the glossary of many economics texts, the definitions proposed differ considerably in their wording, and often in their substantive content.

1. "Structural rate of unemployment" — see "natural rate of unemployment" — "the unemployment rate at which price and wage decisions are consistent", Olivier Blanchard and Angelo Melino (1998), Macroeconomics: First Canadian Edition, p. G5-6, Prentice Hall Canada, Toronto.

2. The long term and chronic unemployment that exists even when the economy is not in a recession is called "structural unemployment", Andrew Abel, Ben Bernanke and Gregor Smith (1995), Macroeconomics: Canadian Edition, p. 6, Addison Wesley Publishers Ltd.

3. "Structural unemployment" arises when there is a mismatch between the skills demanded and supplied in a given area or an imbalance between the supplies of and demand for workers across areas. Ron Ehrenberg and Robert Smith (1997), Modern Labour Economics: Theory and Public Policy, Addison Wesley Publishers, Don Mills, Ontario.

4. "Structural unemployment" occurs because instead of a single labour market, we have a great number of submarkets for particular jobs with specialized skills and qualifications...thus it is possible, even normal, to have an excess of vacancies over unemployed workers in some markets coexisting with an excess of workers over vacancies in others. Vacancies and unemployed cannot get together and cancel out, but simply coexist. Unemployment arising in this way is usually called "structural". Lloyd G. Reynolds, Stanley Masters and Colletta Moser (1998), Labour Economics and Labour Relations (11th Edition), Prentice Hall, New Jersey.

5. Even when the number of jobs equals the number of workers willing to supply themselves, there may be unemployed workers if there is "mismatch" between the types of workers demanded and the type supplied.....Unemployment that arises in this way is usually referred to as "structural unemployment". Chris Bruce (1995), Economics of Employment and Earnings: A Canadian Perspective, p. 572, Nelson Canada.

6. "Structural unemployment results when the skills and location of the unemployed are not matched with the characteristics of the job vacancies". Morley Gunderson and Craig Riddell (1988), Labour Market Economics: Theory, Evidence and Policy in Canada (2nd Edition), McGraw-Hill Ryerson, Toronto.

7. "Structural: Long duration unemployment arising from structural changes in the character of the demand for labour that requires some form of transformation of labour supply". Sylvia Ostry and Mahmood Zaidi (1972) Labour Economics in Canada (2nd Edition), p. 130, Macmillan of Canada, Toronto.

The "mismatch" definition of structural unemployment is also adopted by Stephen Peitchinis (1970), Canadian Labour Economics: An Introductory Analysis (McGraw-Hill, Toronto) and by J.T. Montague (1970), Labour Markets in Canada: Processes and Institutions, Prentice Hall, Scarborough. Interestingly, at this point in time the "structural" approach to unemployment is characterized as a bit suspect, having taken shape first in the minds of administrators, as opposed 
to academic enquiry (Montague 1970:140). Montague is quite sceptical of the possibility of distinguishing clearly between structural and demand deficient unemployment and Peitchinis remarks "there is no agreement amongst economists regarding the significance of structural unemployment" (1970:255).

The "mismatch" definition of structural unemployment has the distinctive advantage that an upper bound to the level of "structural" unemployment can be independently derived, if data on vacancies ("available jobs") can be found. It is clearly circular to argue that persistently high levels of unemployment are "structural" in nature, if structural unemployment is defined to be persistent unemployment. Defining structural unemployment to be "equilibrium" unemployment has the disadvantage of ignoring entirely the extent of frictional unemployment in short-term job search (for which entirely different microeconomic labour market policies are appropriate). As well, there is the difficulty of assessing what equilibrium unemployment might be (or which equilibrium, if there is more than one).

Part of the confusion in usage of the term "structural unemployment" may arise because econometricians have long referred to the "structural form" of macroeconomic models (e.g., Johnston (1972), Econometric Methods, McGraw-Hill p. 4). Estimation of a model of aggregate unemployment can be used to yield a predicted level of unemployment which might be labelled "structural", in the sense of being the rate of unemployment that is predicted by the structural parameters of the model and the current value of exogenous variables. It is clear, for example, that the IMF has often used the term "structural unemployment" in this sense (see Eswar Prasad, "The Canadian Labour Market — Developments, Prospects and Policy", Working Paper/94/97 or Caroline Van Rijckeghem, "Endogeneity in Structural Unemployment Equations: The Case of Canada", Working Paper 93/94.)

However, the structural estimating equation for unemployment might well include the effects of many influences which have nothing to do with unfilled "available jobs" — such variables as seasonal dummies, the US unemployment rate, the youth percentage of the labour force, etc. Although the same word (structural) occurs, this is a fundamentally different concept from the "mismatch" concept — but when this is not recognized, macroeconomic analysts can often shift casually from one meaning of the term "structural" to another. 


\section{Appendix B \\ Newspapers Covered in the Help-Wanted Index Survey}

\begin{tabular}{ll}
\hline Region & Newspaper \\
\hline Atlantic: & $\begin{array}{l}\text { St. John's Evening Telegram, Charlottetown Guardian, Halifax Chronicle Herald, Saint } \\
\text { John Telegraph Journal, Moncton Times Transcript* }\end{array}$ \\
Quebec: & $\begin{array}{l}\text { Quebec Le Soleil, Sherbrooke La Tribune, Montreal Gazette, Montreal La Presse, } \\
\text { Ottawa-Hull Le Droit, Ottawa-Hull Citizen* }\end{array}$ \\
Ontario: & $\begin{array}{l}\text { Ottawa-Hull Le Droit, Ottawa-Hull Citizen*, Toronto Star, Hamilton Spectator, London } \\
\text { Free Press, Sudbury Star* }\end{array}$ \\
Prairie: & Winnipeg Free Press, Regina Leader Post, Saskatoon Star Phoenix*, \\
BC: & Edmonton Journal, Calgary Herald \\
\hline
\end{tabular}

\footnotetext{
* Added to the new series.
} 
Appendix C

Estimated Unemployment Rate and Help-Wanted Index Equations, 1981:01-1999:03

\begin{tabular}{|c|c|c|c|c|}
\hline \multirow[b]{2}{*}{ Indep. Var. } & \multicolumn{2}{|c|}{ OLS for Canada } & \multicolumn{2}{|c|}{ Full-Pooling across Provinces } \\
\hline & Dep. Var. = URATE & Dep. Var. = HWI & Dep. Var. = URATE & Dep. Var. = HWI \\
\hline \multirow[t]{2}{*}{ Intercept } & 13.5470 & 414.1400 & 11.2990 & 96.2730 \\
\hline & $(20.89)$ & $(12.03)$ & $(13.46)$ & $(26.95)$ \\
\hline \multirow[t]{2}{*}{ HWI } & -0.0461 & & -0.0259 & \\
\hline & $(-5.50)$ & & $(-2.62)$ & \\
\hline \multirow[t]{2}{*}{$(\mathrm{HWI})^{2}$} & 0.00004 & & 0.00002 & \\
\hline & $(1.61)$ & & $(0.79)$ & \\
\hline \multirow[t]{2}{*}{ URATE } & & -53.5930 & & -0.2278 \\
\hline & & $(-6.09)$ & & $(-1.68)$ \\
\hline \multirow[t]{2}{*}{$(\text { URATE })^{2}$} & & 2.0556 & & 0.0055 \\
\hline & & $(3.79)$ & & $(1.30)$ \\
\hline \multirow{2}{*}{ TIME } & 0.0283 & 1.1061 & 0.0080 & 0.1828 \\
\hline & $(8.66)$ & $(20.05)$ & $(2.09)$ & $(6.62)$ \\
\hline \multirow{2}{*}{ TIME*1990s } & -0.0244 & -0.9455 & -0.0051 & -0.0333 \\
\hline & $(-9.01)$ & $(-23.15)$ & $(-2.01)$ & $(-2.07)$ \\
\hline \multirow[t]{2}{*}{ FEB } & -0.1413 & -2.5236 & -0.1002 & 0.2067 \\
\hline & $(-0.60)$ & $(-0.44)$ & $(-1.48)$ & $(0.51)$ \\
\hline \multirow[t]{2}{*}{ MARCH } & 0.1151 & 0.8891 & 0.2842 & 0.3767 \\
\hline & $(0.49)$ & $(0.16)$ & (3.12) & $(0.69)$ \\
\hline \multirow[t]{2}{*}{ APRIL } & -0.3368 & -6.6175 & -0.1912 & 0.2801 \\
\hline & $(-1.41)$ & $(-1.14)$ & $(-1.80)$ & $(0.44)$ \\
\hline \multirow[t]{2}{*}{ MAY } & -1.1169 & -21.6660 & -1.3533 & 0.2588 \\
\hline & $(-4.67)$ & $(-3.66)$ & $(-11.71)$ & $(0.37)$ \\
\hline \multirow[t]{2}{*}{ JUNE } & -1.5729 & -31.8470 & -2.1389 & 0.0781 \\
\hline & $(-6.58)$ & $(-5.31)$ & $(-17.69)$ & $(0.11)$ \\
\hline \multirow[t]{2}{*}{ JULY } & -1.4330 & -28.8790 & -1.7282 & -0.3221 \\
\hline & $(-5.99)$ & $(-4.84)$ & $(-14.08)$ & $(-0.44)$ \\
\hline \multirow[t]{2}{*}{ AUGUST } & -1.1679 & -23.6850 & -2.0801 & -0.0085 \\
\hline & $(-4.88)$ & $(-4.00)$ & $(-17.14)$ & $(-0.12)$ \\
\hline \multirow[t]{2}{*}{ SEPT } & -1.6821 & -34.6490 & -2.4520 & -0.0967 \\
\hline & $(-7.03)$ & $(-5.77)$ & $(-21.02)$ & $(-0.14)$ \\
\hline \multirow[t]{2}{*}{ OCT } & -1.6272 & -33.7670 & -2.3457 & 0.0112 \\
\hline & $(-6.79)$ & $(-5.63)$ & $(-21.73)$ & $(0.17)$ \\
\hline \multirow[t]{2}{*}{ NOV } & -1.2507 & -26.5260 & -1.5152 & 0.1097 \\
\hline & $(-5.22)$ & $(-4.48)$ & $(-16.13)$ & $(0.19)$ \\
\hline \multirow[t]{2}{*}{ DEC } & -1.0150 & -22.1030 & -1.3442 & -0.0681 \\
\hline & $(-4.23)$ & $(-3.76)$ & $(-18.91)$ & $(-0.16)$ \\
\hline
\end{tabular}

(continued) 


\section{Appendix C (continued)}

Estimated Unemployment Rate and Help-Wanted Index Equations, 1981:01-1999:03

\begin{tabular}{|c|c|c|c|c|}
\hline \multirow[b]{2}{*}{ Indep. Var. } & \multicolumn{2}{|c|}{ OLS for Canada } & \multicolumn{2}{|c|}{ Full-Pooling across Provinces } \\
\hline & Dep. Var. = URATE & Dep. Var. = HWI & Dep. Var. = URATE & Dep. Var. = HWI \\
\hline \multirow[t]{2}{*}{ NFLD } & & & 10.8970 & 31.2820 \\
\hline & & & $(18.68)$ & $(7.79)$ \\
\hline \multirow[t]{2}{*}{ PEI } & & & 7.5123 & 43.5840 \\
\hline & & & $(8.05)$ & $(9.03)$ \\
\hline \multirow[t]{2}{*}{ NS } & & & 4.6528 & 26.0620 \\
\hline & & & $(8.52)$ & (4.44) \\
\hline \multirow[t]{2}{*}{ NB } & & & 5.3926 & 21.5480 \\
\hline & & & $(9.24)$ & $(6.31)$ \\
\hline \multirow[t]{2}{*}{ QUE } & & & 3.0938 & -17.8890 \\
\hline & & & $(7.37)$ & $(-5.85)$ \\
\hline \multirow[t]{2}{*}{ MAN } & & & -0.3770 & -9.0641 \\
\hline & & & $(-0.85)$ & $(-4.94)$ \\
\hline \multirow[t]{2}{*}{ SASK } & & & -0.8110 & 8.9991 \\
\hline & & & $(-1.81)$ & $(4.37)$ \\
\hline \multirow[t]{2}{*}{ ALTA } & & & -0.2195 & -2.6682 \\
\hline & & & $(-0.47)$ & $(-1.23)$ \\
\hline \multirow[t]{2}{*}{$\mathrm{BC}$} & & & 2.5192 & 27.7450 \\
\hline & & & $(3.54)$ & $(3.64)$ \\
\hline $\mathrm{N}$ & \multicolumn{2}{|c|}{219} & \multicolumn{2}{|c|}{2190} \\
\hline
\end{tabular}

(continued) 


\section{Appendix C (continued)}

Estimated Unemployment Rate and Help-Wanted Index Equations, 1981:01-1999:03

\begin{tabular}{|c|c|c|c|c|}
\hline \multirow[b]{2}{*}{ Indep. Var. } & \multicolumn{2}{|c|}{ OLS for Canada } & \multicolumn{2}{|c|}{ Full-Pooling across Provinces } \\
\hline & Dep. Var. = URATE & Dep. Var. = HWI & Dep. Var. = URATE & Dep. Var. = HWI \\
\hline \multirow[t]{2}{*}{ Intercept } & 12.45800 & 420.55000 & 10.30900 & 109.61000 \\
\hline & $(26.06)$ & $(11.22)$ & $(13.38)$ & $(23.27)$ \\
\hline \multirow[t]{2}{*}{ HWI } & -0.04349 & & -0.02937 & \\
\hline & $(-7.25)$ & & $(-3.32)$ & \\
\hline \multirow[t]{2}{*}{$(\mathrm{HWI})^{2}$} & 0.00006 & & 0.00003 & \\
\hline & $(3.02)$ & & $(0.93)$ & \\
\hline \multirow[t]{2}{*}{ URATE } & & -42.95600 & & -0.14755 \\
\hline & & $(-4.52)$ & & $(-1.14)$ \\
\hline \multirow[t]{2}{*}{$(\mathrm{URATE})^{2}$} & & 0.66296 & & 0.00355 \\
\hline & & $(1.14)$ & & $(0.86)$ \\
\hline \multirow[t]{2}{*}{ TIME } & 0.04344 & 1.63380 & 0.04948 & -0.13016 \\
\hline & $(17.53)$ & $(18.87)$ & $(7.40)$ & $(-1.62)$ \\
\hline \multirow[t]{2}{*}{$(\mathrm{TIME})^{2}$} & -0.00020 & -0.00775 & -0.00022 & 0.00116 \\
\hline & $(-18.14)$ & $(-20.52)$ & $(-7.37)$ & $(3.27)$ \\
\hline \multirow[t]{2}{*}{ FEB } & -0.12736 & -3.81820 & -0.09329 & 0.36756 \\
\hline & $(-0.74)$ & $(-0.61)$ & $(-1.44)$ & $(1.05)$ \\
\hline \multirow[t]{2}{*}{ MARCH } & 0.14637 & 4.54700 & 0.31272 & 0.55487 \\
\hline & $(0.85)$ & $(0.73)$ & (3.60) & (1.18) \\
\hline \multirow[t]{2}{*}{ APRIL } & -0.37432 & -12.05200 & -0.15977 & 0.51780 \\
\hline & $(-2.14)$ & $(-1.90)$ & $(-1.58)$ & (0.94) \\
\hline \multirow[t]{2}{*}{ MAY } & -1.13840 & -36.32800 & -1.34470 & 0.48277 \\
\hline & $(-6.52)$ & $(-5.63)$ & $(-12.26)$ & $(0.80)$ \\
\hline \multirow[t]{2}{*}{ JUNE } & -1.57650 & -50.65100 & -2.15150 & 0.28723 \\
\hline & $(-9.03)$ & $(-7.75)$ & $(-18.79)$ & $(0.45)$ \\
\hline \multirow[t]{2}{*}{ JULY } & -1.41850 & -45.41900 & -1.73390 & -0.19086 \\
\hline & $(-8.12)$ & $(-6.98)$ & $(-14.93)$ & $(-0.30)$ \\
\hline \multirow[t]{2}{*}{ AUGUST } & -1.13490 & -36.21100 & -2.08750 & -0.04877 \\
\hline & $(-6.50)$ & $(-5.61)$ & $(-18.18)$ & $(-0.77)$ \\
\hline \multirow[t]{2}{*}{ SEPT } & -1.62970 & -52.20300 & -2.47130 & -0.29312 \\
\hline & $(-9.33)$ & $(-7.97)$ & $(-22.41)$ & $(-0.48)$ \\
\hline \multirow[t]{2}{*}{ OCT } & -1.55530 & -49.77500 & -2.36860 & -0.02226 \\
\hline & $(-8.90)$ & $(-7.61)$ & $(-23.21)$ & $(-0.40)$ \\
\hline \multirow[t]{2}{*}{ NOV } & -1.15790 & -36.97800 & -1.52300 & 0.17226 \\
\hline & $(-6.63)$ & $(-5.73)$ & $(-17.17)$ & $(0.35)$ \\
\hline \multirow[t]{2}{*}{ DEC } & -0.90264 & -28.73800 & -1.33240 & 0.13921 \\
\hline & $(-5.17)$ & $(-4.48)$ & $(-20.01)$ & $(0.38)$ \\
\hline
\end{tabular}

(continued) 
Appendix C (concluded)

Estimated Unemployment Rate and Help-Wanted Index Equations, 1981:01-1999:03

\begin{tabular}{|c|c|c|c|c|}
\hline \multirow[b]{2}{*}{ Indep. Var. } & \multicolumn{2}{|c|}{ OLS for Canada } & \multicolumn{2}{|c|}{ Full-Pooling across Provinces } \\
\hline & Dep. Var. = URATE & Dep. Var. = HWI & Dep. Var. = URATE & Dep. Var. = HWI \\
\hline NFLD & & & $\begin{array}{r}10.86700 \\
(19.63)\end{array}$ & $\begin{array}{r}33.55000 \\
(5.27)\end{array}$ \\
\hline PEI & & & $\begin{array}{r}7.44260 \\
(8.41)\end{array}$ & $\begin{array}{r}45.90000 \\
(9.35)\end{array}$ \\
\hline NS & & & $\begin{array}{r}4.63480 \\
(9.69)\end{array}$ & $\begin{array}{r}31.09100 \\
(6.24)\end{array}$ \\
\hline NB & & & $\begin{array}{r}5.34520 \\
(9.29)\end{array}$ & $\begin{array}{r}21.17000 \\
\quad(4.66)\end{array}$ \\
\hline QUE & & & $\begin{array}{r}2.97630 \\
(6.87)\end{array}$ & $\begin{array}{r}-16.95000 \\
(-3.07)\end{array}$ \\
\hline MAN & & & $\begin{array}{r}-0.48063 \\
(-1.13)\end{array}$ & $\begin{array}{r}-9.51140 \\
(-4.48)\end{array}$ \\
\hline SASK & & & $\begin{array}{r}-0.86860 \\
(-1.97)\end{array}$ & $\begin{array}{r}15.58500 \\
(2.58)\end{array}$ \\
\hline ALTA & & & $\begin{array}{r}-0.22044 \\
(-0.50)\end{array}$ & $\begin{array}{r}-2.94100 \\
(-1.12)\end{array}$ \\
\hline $\mathrm{BC}$ & & & $\begin{array}{r}2.65800 \\
(3.63)\end{array}$ & $\begin{array}{r}34.49400 \\
(3.70) \\
\end{array}$ \\
\hline $\mathrm{N}$ & 21 & & 219 & \\
\hline
\end{tabular}

Note: Asymptotic t-ratios are given in parentheses. 


\section{Appendix D \\ Industry/Province Combination of the 1996 Workplace and Employee Survey}

\begin{tabular}{lrrrr}
\hline & \multicolumn{2}{c}{ Establishments } & \multicolumn{2}{c}{ Employment } \\
\cline { 2 - 5 } Industry/Province & $\begin{array}{r}\text { Sample } \\
\text { size }\end{array}$ & $\begin{array}{r}\text { Estimated } \\
\text { population }\end{array}$ & $\begin{array}{r}\text { Sample } \\
\text { size }\end{array}$ & $\begin{array}{r}\text { Estimated } \\
\text { population }\end{array}$ \\
\hline Logging, forestry, mining, quarries, and oil wells - Quebec, & 58 & 3,430 & 152 & 68,092 \\
$\quad$ British Columbia & & & & \\
Manufacturing: science-based — Canada & 78 & 4,709 & 243 & 219,135 \\
Scale-based manufacturing - Ontario & 73 & 4,586 & 115 & 349,477 \\
$\quad$ Transportation, storage, wholesale - Manitoba, & 71 & 14,352 & 241 & 241,646 \\
$\quad$ Saskatchewan, Alberta & & & & \\
Retail trade and commercial services - Manitoba, & 46 & 11,897 & 130 & 235,200 \\
$\quad$ Saskatchewan & & & & \\
Finance and insurance - Quebec & 39 & 3,316 & 149 & 118,465 \\
Real estate operations and insurance agents - Ontario & 66 & 12,699 & 162 & 103,375 \\
Business services - Alberta & 42 & 3,251 & 139 & 72,563 \\
Construction - all regions except Manitoba, Saskatchewan, & 48 & 34,915 & 36 & 150,594 \\
$\quad$ Alberta & & & & \\
Communications and other utilities - Canada & 47 & 503 & 158 & 361,557 \\
Education and health services - Atlantic provinces, Quebec & 38 & 100 & 125 & 229,410 \\
Manufacturing: product-differentiated - Canada & 75 & 1,735 & 148 & 162,939 \\
Other & 67 & 19,447 & 162 & 307,519 \\
Total & 748 & 114,940 & 1,960 & $2,619,972$ \\
\hline Source: Sta
\end{tabular}

Source: Statistics Canada/HRDC (1998), The Evolving Workplace: Findings from the Pilot Workplace and Employee Survey, Ottawa: Catalogue 71-583. 


\section{References}

Abel, A.B., B. Bernanke and G.W. Smith (1999), Macroeconomics: Second Canadian Edition Addison-Wesley, Don Mills, Ontario

Bastelaer and Laan (1994), in J. Muysken (ed.), Measurement and Analysis of Job Vacancies: An International Comparison, Aldershot, UK: Avebury Press.

Boothby, D. (1995), COPS: A Revised Demand Side, Ottawa: Applied Research Branch, Human Resource Development Canada, Technical Document T-95-4.

Branham Group Incorporated (1999), IT Skills Shortage in Canada - A Snapshot, A report prepared for the Information Technology Association of Canada, February 4, 1999, mimeo (available from the ITAC website - www.itac.ca).

Burdett, K. and E. Cunningham (1994), “The Duration of a Vacancy”, in J. Muysken (editor), Measurement and Analysis of Job Vacancies: An International Comparison (1994), pp. 147-168.

CLMPC (1988), "The Nature of Current Unemployment: Evidence from Job Vacancy Information", pp. 31-34, Quarterly Labour Market and Productivity Review, Ottawa: The Canadian Labour Market and Productivity Centre, 1988.

Dupasquier, C., A. Guay, and P. St-Amant (1997), "A Comparison of Alternative Methodologies for Estimating Potential Output and the Output Gap", Bank of Canada Working Paper 9705, February 1997.

Evans, M. (1999), "High Tech Sector Expected to Add 30,000 Jobs in Two Years", The Globe and Mail: Report on Business, February 10, 1999, p. B8.

Gera, S., S. Rahman and J. Arcand (1991), "Structural Imbalances in Canadian Labour Markets", Working Paper No. 18, Economic Council of Canada, Ottawa, 1991.

Granovetter, M.S. (1974), Getting a Job: A study of Contacts and Careers, Cambridge, Mass.: Harvard University Press, 1974.

Greater Halifax Partnership (1997), Listening to Business 1997, Halifax Regional Municipality, April 1997, mimeo.

Haggar-Guenette, C. (1988), "The 'Old' and the 'Revised' Help-Wanted Index: A Comparison", Help-Wanted Index 1988, 33-35, Ottawa: Statistics Canada, Catalogue 71-204.

Hamilton, T. (1999), “Tech Skill Shortage Hurts Firms”, Report On Business, The Globe and Mail, January 19, 1999, p. B8. 
Henson, H. and C. Newton (1996), "Tools and Methods for Identifying Skill Shortages: A CrossCoutry Comparison", Technical Document T-96-3E, Applied Research Branch, Strategic Policy, Human Resource Development Canada, Ottawa.

Jackson, A. (1998), "The NAIRU and the Macroeconomic Policy in Canada", Canadian Labour Congress, Ottawa, 1998, mimeo.

Muysken, J. (1994), Measurement and Analysis of Job Vacancies: An International Comparison, Avebury Press, Aldershot, UK, 1994.

Nova Knowledge (1998), Nova Scotia's Knowledge Economy Report Card: 1998, mimeo, Halifax, 1998 (http://www.novaknowledge.ns.ca).

Nova Scotia Labour Market Development Secretariat (1999a), Toward an Integrated Labour Market Framework: A Consultation with Nova Scotia's Labour Market Partners, Executive Summary, Halifax, 1999.

Nova Scotia Labour Market Development Secretariat (1999b), Toward an Integrated Labour Market Framework: A Consultation with Nova Scotia's Labour Market Partners, Main Report, Halifax, February 1999.

Osberg, L. (1991), "Unemployment and Inter-industry labour mobility in Canada in the 1980's", Applied Economics, Vol. 23, No. 11, pp. 1707-18.

Osberg, L. (1993), "Fishing in Different Pools - Job Search Strategies and Job-Finding Success in Canada in the Early 1980's", Journal of Labour Economics, Volume 11, No. 2, pp. 34886.

Ostry, S. and A. Sunter (1970), "Definitional and Design Aspects of the Canadian Job Vacancy Survey", Journal of the American Statistical Association, 65 (September), 1059-70.

Reid, F. and N. Meltz (1979), "Causes of Shifts in the Unemployment-Vacancy Relationship: An Empirical Analysis for Canada”, Review of Economics and Statistics, 61 (3), 470-75.

Rothschild, K. (1993), Employment, Wages and Income Distribution: Critical Essays in Economics, Routledge, London and New York, 1993.

Roy, R., H. Henson and C. Lavoie (1996), “A Primer on Skill Shortages in Canada”, Applied Research Branch, Human Resource Development Canada, R-96-8E, Ottawa.

Sargent, T. and M. Sheikh (1996), "The Natural Rate of Unemployment: Theory, Evidence and Policy Implications", Economic Studies and Policy Analysis Division, Department of Finance, Ottawa, August 1996. 
Sharpe, A. (1999), "The Nature and Causes of Unemployment in Canada", in Employment Policy Options, pp. 3-50, Ottawa: The Caledon Institute of Social Policy, 1999.

Statistics Canada, Historical Labour Force Statistics 1993, Ottawa: Catalogue 71-201.

Statistics Canada, Help-Wanted Index 1988, Ottawa: Catalogue 71-204.

Statistics Canada, Help-Wanted Index 1987, Ottawa: Catalogue 71-204.

Statistics Canada, Annual Report on Job Vacancies 1978, Ottawa: Catalogue 71-203.

Statistics Canada, The Canadian Job Vacancy Survey: Technical Appendix, Ottawa: Catalogue 71-521.

Statistics Canada (1998), The Evolving Workplace: Findings from the Pilot Workplace and Employee Survey, Ottawa: Catalogue No. 71-583.

Torjman, S. and K. Battle (1999), Good Work: Getting It and Keeping It, Caledon Institute of Social Policy, Ottawa, February 1999. 